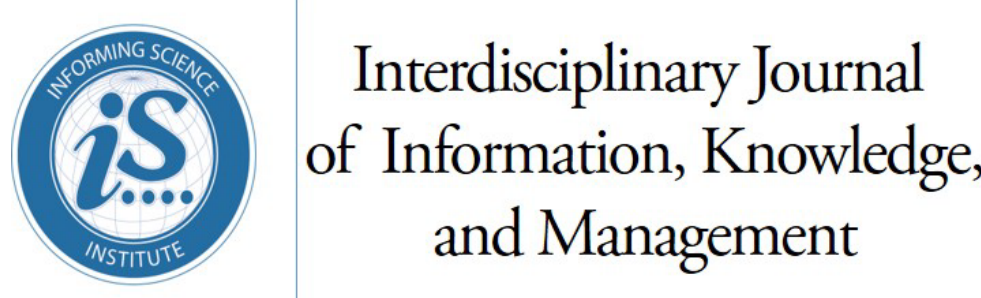

An Official Publication

of the Informing Science Institute

InformingScience.org

IJIKM.org

Volume 16, 2021

\title{
STUdENTS' CONTINUANCE INTENTION TO USE MOODLE: AN EXPECTATION-CONFIRMATION MODEL APPROACH
}

\begin{tabular}{lll}
\hline Ahmad A. Rabaa'i* & $\begin{array}{l}\text { New Jersey City University, School of } \\
\text { Business, Jersey City, NJ, USA }\end{array}$ & arabaai@,njcu.edu \\
Shareef Abu AlMaati & $\begin{array}{l}\text { American University of Kuwait, } \\
\text { Salmiya, Kuwait }\end{array}$ & smaati@,auk.edu.kw \\
Xiaodi Zhu & $\begin{array}{l}\text { New Jersey City University, School of } \\
\text { Business, Jersey City, NJ, USA }\end{array}$ & \\
$*$ Corresponding nou.edu &
\end{tabular}

\section{ABSTRACT}

Aim/Purpose

This study aims at investigating the factors that influence students' continuous intention to use Moodle, as an exemplar of learning management systems (LMSs), in the post-adoption phase.

Background

Higher education institutions (HEIs) have invested heavily in learning management systems (LMSs), such as Moodle and BlackBoard, as these systems enhance students' learning and improve their interactions with the educational systems. While most studies on LMSs have focused on the pre-adoption or acceptance phases of this technology, the determinant factors that influence students' continuance intention to use LMSs have received less attention in the information systems (IS) literature.

Methodology The theoretical model for this study was primarily drawn from the expectationconfirmation model (ECM). A total of 387 Kuwaiti students, from a private American University in the State of Kuwait, participated in this study. Partial least squares (PLS) was employed to analyze the data.

Contribution

This study contributes to the existing scientific knowledge in different ways. First, this study extends the expectation confirmation model (ECM) by integrating factors that are important to students' continuous intention to use LMSs, including system interactivity, effort expectancy, attitude, computer anxiety, selfefficacy, subjective norms, and facilitating conditions. Second, this study adds on a Kuwaiti literature context by focusing on the continuous intention to use

Accepting Editor Nelson K. Y. Leung | Received: April 9, 2021 | Revised: June 21, July 21, 2021 | Accepted: August 3, 2021.

Cite as: Rabaa'i, A. A., AlMaati, S. A., \& Zhu, X. (2021). Students' continuance intention to use Moodle: An expectation-confirmation model approach. Interdisciplinary Journal of Information, Knowledge, and Management, 16, 397-434. https://doi.org/10.28945/4842

(CC BY-NC 4.0) This article is licensed to you under a Creative Commons Attribution-NonCommercial 4.0 International License. When you copy and redistribute this paper in full or in part, you need to provide proper attribution to it to ensure that others can later locate this work (and to ensure that others do not accuse you of plagiarism). You may (and we encourage you to) adapt, remix, transform, and build upon the material for any non-commercial purposes. This license does not permit you to use this material for commercial purposes. 
Findings

Recommendations for Practitioners

Recommendations for Researchers

Impact on Society

Future Research

Keywords
LMSs, which is, to the best of our knowledge, the first study that extends and empirically assesses the applicability of the ECM in the LMSs context in a developing country - Kuwait. Third, this study conceptually and empirically differentiates between satisfaction and attitude, as two separate affect constructs, which were taken as interchangeable factors in ECM, and were disregarded by a large number of prior ECM studies concerned with continuous use intention. Finally, this study aims to assist HEIs, faculty members, and systems' developers in understanding the main factors that influence students' continuance use intention of LMSs.

While subjective norms were not significant, the results mainly showed that students' continuous intention to use Moodle is significantly influenced by performance expectancy, effort expectancy, attitude, satisfaction, self-efficacy and facilitating conditions. The study's results also confirmed that satisfaction and attitude are two conceptually and empirically different constructs, conflicting with the views that these constructs can be taken as interchangeable factors in the ECM.

This study offers several useful practical implications. First, given the significant influence of system interactivity on performance expectancy and satisfaction, faculty members should modify their teaching approach by enabling communication and interaction among instructors, students, and peers using the LMS. Second, given the significant influence of performance expectancy, satisfaction, and attitude on continuous intention to use the LMS, HEIs should conduct training programs for students on the effective use of the LMS. This would increase students' awareness regarding the usefulness of the LMS, enhance their attitude towards the LMS, and improve their satisfaction with the system. Third, given the significant role of effort expectancy in influencing performance expectancy, attitude, and students' continuous intention to use Moodle, developers and system programmers should design the LMS with easy to use, high quality, and customizable user interface. This, in turn, will not only motivate students' performance expectancy, but will also influence their attitude and continuous intention to use the system.

This study conceptually and empirically differentiates between satisfaction and attitude, as two separate affect constructs, which were taken as interchangeable factors in ECM and were disregarded by a large number of prior ECM studies concerned with continuous use intention. Hence, it is recommended that researchers include these two constructs in their research models when investigating continuous intention to use a technology.

This study could be used in other countries to compare and verify the results. Additionally, the research model of this study could also be used to investigate other LMSs, such as Blackboard.

This study focused on how different factors affected students' continuous intention to use Moodle but did not consider all determinants of successful system, such as system quality, information quality, and instructional as well as course content quality. Thus, future research should devote attention to the effects of these quality characteristics of LMS.

continuance use, expectation confirmation model (ECM), Kuwait, learning management systems (LMS), Moodle 


\section{INTRODUCTION}

Traditionally, higher education institutions (HEIs) used conventional (traditional, face-to-face) teaching methods. The conventional teaching method is instructor-centered, and the contents or learning materials were provided by the instructor, and every student has to study the same topic at the same time provided by the instructor (Shakya et al., 2017). Although conventional teaching methods have been espoused for providing an opportunity for students to learn directly from subject experts, such methods can lack flexibility, do not ensure teaching consistency, nor accommodate the diverse learning needs of students (Bloomfield et al., 2010, p. 288). Nevertheless, the developments in information and communication technologies (ICTs) have reshaped various industries, such as health, retail, business, finance, and education. As a result, HEIs are responding to these technological advancements by adopting various electronic learning (e-learning) technologies that have shifted the education system from conventional learning to e-learning, and this is relevant for the learner as it is providing flexibility in learning with optional choices for study to the learner with unlimited access to information (Khadka et al., 2020, p. 105). E-learning is an "innovative approach to education delivery via electronic forms of information that enhances the learner's knowledge, skills, or other performance" (Siritongthaworn et al., 2006, p. 138). E-learning has various benefits, such as personalized learning, increased access to information, effective means to standardize and deliver content, on-demand content availability, interactivity, and provides flexible, convenient, and diverse learning environments to meet the disparate needs of learners (Lwoga, 2014, p. 4).

Among a variety of e-learning technologies, learning management systems (LMSs) are consistently considered the most important technology adopted in higher education today (e.g., Green \& Chewning, 2020; Rhode et al., 2017). A LMS is capable of transforming face-to-face sessions by offering students a space for online learning (Wichadee, 2015). Using a LMS is an effective way of delivering instruction to students by offering $24 / 7$ access to course content, while enabling convenient course creation and management for teachers (Fearnley \& Amora, 2020, p. 91). The adoption of LMSs has resulted in an increasingly important role of these systems in contemporary education system (Ifinedo et al., 2018). LMSs can support student learning by enabling the sharing of learning material online, allowing additional learning components, such as quizzes, presentations, screencasts, assignments, and discussion forums, and allow teachers to provide and manage these resources in a relatively easy and integrated way (Conijn et al., 2017). In fact, LMSs have become an influential and integrated piece of the higher education infrastructure, and the LMSs market is currently valued at over $\$ 9$ billion, with a projected global market value of $\$ 22.4$ billion by 2023 (Green \& Chewning, 2020).

Moodle - Modular Object-Oriented Dynamic Learning Environment - is one of the most popular LMSs. It is used extensively across the world because it is easy to use, users can customize the platform to meet their organizational objectives, and it offers a wide range of services for both educators and students (Pérez-Pérez et al., 2019). Moodle allows for the management of subject contents (documents, graphics, web pages or videos), communication with students (i.e., forums or virtual tutorials), and students' assessment (i.e., grading or monitoring subject assignments) (Susana et al., 2015, p. 605). At present, there are more than 96 thousand registered sites, more than 20 million courses, and more than 180 million registered from 232 countries all over the world using Moodle (Moodle, 2020).

The IS literature indicates that the preponderance of research focused on LMSs tends to be placed on the following themes: the importance of LMS in effective instructional delivery (e.g., Ali et al., 2018; El Mawas et al., 2016; Kuhnel et al., 2018; Mubin et al., 2017), LMSs features (e.g., Echeverria et al., 2013; Mpungose, 2020; Oh et al., 2018), adoption and acceptance (e.g., Ali et al., 2018; M. Cheng \& Yuen, 2019; Ifinedo et al., 2018; Pérez-Pérez et al., 2019), and implementation success (e.g., Al-Fraihat et al., 2020; Eom \& Ashill, 2018; Seta et al., 2018). For instance, Cidral et al. (2018) generally classified e-learning studies from 2001 till 2016. The authors reported that studies from 2001 started with a focus on intention to use, adoption, usability, course contents, and customization, and evolved later to include satisfaction from 2007. From 2013, studies have focused on the overall 
success of e-learning and on how students' performance and achievements affect e-learning. Additionally, IS scholars have used different theoretical models to investigate the factors that influence the pre-adoption or acceptance phases of LMSs, such as the unified theory of acceptance and use of technology (UTAUT) and (UTAUT2), technology acceptance model (TAM), innovation diffusion theory (IDT), theory of planned behavior (TPB), DeLone and McLean IS-Success Model, or used different combinations of these theories.

While the significant amount of prior research in LMSs has deepened our understanding of the pivotal adoption, acceptance and success factors of these systems, such as information quality, system quality, service quality, satisfaction, attitude, usefulness, ease of use, communicativeness, perceived learning outcomes and students' performance and achievements, there has been limited research specifically on continuance use of LMSs (e.g., M. Cheng \& Yuen, 2018, 2019; Shiue \& Hsu, 2017). For instance, as reported by Cidral et al. (2018), earlier studies have been concerned more about the technology itself. However, as the technology becomes increasingly reliable and accessible (Al-Fraihat et al., 2020), recent research should focus more on the continuous intention to use the technology, which plays a vital role in the success of these systems. In fact, it is argued that the main determinant of IS success is its continued use (e.g., Al-Emran et al., 2020; Foroughi et al., 2019; Sabah, 2019; Susanto et al., 2016). Further, more recently, the growth of LMSs is challenged by institutional barriers and negative users' perceptions (e.g., Ali et al., 2018; Green \& Chewning, 2020; Gunasinghe et al., 2019a, 2019b). Thus, this study aims at understanding the factors that influence students' continuance intention to use Moodle (as an exemplar of LMSs) in the post-adoption phase.

The majority of the IS literature in the LMSs context focusses on the pre-adoption or acceptance phases of LMS. Only a few studies (e.g., Al-Emran et al., 2020; M. Cheng \& Yuen, 2018; Dai et al., 2020; Sabah, 2019) examined post-adoption continuous intentions and behaviors. Additionally, theories, such as TAM, IDT, UTAUT, and TPB, are primarily used to explain users' pre-adoption behaviors (Foroughi et al., 2019), and has numerous limitations in predicting the users' continuance behaviors in the post-adoption phase (Joo et al., 2018). Prior studies (e.g., Bhattacherjee, 2001a, 2001b; Oertzen \& Odekerken-Schröder, 2019) argued that users may start using more functional digital features only in the post-adoption phase, after they have gained some experience with the technology. As such, there is a need to study IS continuous use intention in the post-adoption phase.

This study contributes to the existing scientific knowledge in different ways. First, this study seeks to investigate students' continuance intention to use Moodle in the post-adoption phase. Second, this study extends the expectation confirmation model (ECM) (Bhattacherjee, 2001a) by integrating factors that are important to students' continuous intention to use LMSs, including system interactivity, effort expectancy, attitude, computer anxiety, self-efficacy, subjective norms, and facilitating conditions. Third, this study adds on the Kuwaiti literature context by focusing on the continuous intention to use LMSs, which is, to the best of our knowledge, the first study that extends and empirically assesses the applicability of the ECM in the LMSs context in a developing country - Kuwait. Fourth, this study goes beyond what was proposed by Bhattacherjee (2001a), in the original ECM, by including a new construct (Attitude) alongside the ECM constructs, and proposing new causal paths (Performance Expectancy ->Attitude and Attitude -> Continuous Intention). Fifth, in line with Dia et al. (2020), this study conceptually and empirically differentiates between satisfaction and attitude, as two separate affect constructs, which were taken as interchangeable factors in ECM (Bhattacherjee, 2001a), and were disregarded by a large number of prior ECM studies concerned with continuous use intention. Finally, this study aims to assist HEIs, faculty members, and systems' developers and programmers in understanding the main factors that influence students' continuance use intention of LMSs.

The rest of the paper proceeds as follows. In the next section, the theoretical background, the research conceptual model and hypotheses development are presented. This is followed by the research methodology. The empirical results are then discussed. Next, the discussion and implications are presented. The study's limitations, future research and conclusion sections end the paper. 


\section{THEORETICAL BACKGROUND, CONCEPTUAL MODEL AND HYPOTHESES DEVELOPMENT}

Users' continued use of different technologies has become a main focus of investigation by scholars, as it shows whether a particular technology is really valuable or nothing more than a gimmick (Rahi et al., 2018, p. 24). Early academic efforts in IS continued use research adopted the same set of motivational variables to explain both acceptance and continuance decisions, treating continuance as an extension of the initial adoption (Ding, 2019). For instance, researchers have used the technology acceptance model (TAM), unified theory of acceptance and use of technology (UTAUT) model, social cognitive theory (SCT), theory of planned behavior (TPB), self-determination theory (SDT), task technology fit (TTF), and innovation diffusion theory (IDT), or attempted to ingrate these theoretical frameworks to investigate the continuous use of IS or new technologies (Sabah, 2019). However, initial acceptance has not naturally translated into the continued use of technology, evidenced by the phenomenon that some users accepted the technology initially but discontinued its use at a later stage (Dai et al., 2020). In fact, it is argued that users' intention to use a technology suggests only their positive attitude toward the technology and their affiliated desire to use it (Huang, 2019), but does not necessarily guarantee their continued use of it (Wang et al., 2019). Since people tend to be curious about a novel technology, they will have a positive attitude toward the technology, followed by the intention to use it (e.g., Alraimi et al., 2015; Rahi et al., 2018). Therefore, initial use or acceptance will not automatically translate into a continuous use of the technology, because users will carefully assess whether they really need the technology or they use it as a transient stage (e.g., Huang, 2019; Merikivi et al., 2017). More specifically, users will continue to use the technology as long as it satisfies their expectations (Huang, 2019), and will stop using the technology when it neither matches their expectations nor fulfills their needs (Bhattacherjee, 2001a).

Developed by Bhattacherjee (2001a) and adapted from the Expectation-Confirmation Theory (ECT) (Oliver, 1980), the Expectation Confirmation Model (ECM) is focused on post-acceptance and postconsumption expectation factors (e.g., Foroughi et al., 2019; Rahi et al., 2018). The ECM focuses on factors that influence constancy and retention, since prior literature argued that the long-term success and viability of an IS are determined by continued use rather than initial adoption or usage (Foroughi et al., 2019, p. 1017). The ECM has been employed to assess individuals' continuous use intention in different technological contexts; for example, blended e-learning intention (Y-M. Cheng, 2014a), digital libraries (Y. M. Cheng, 2014b), cloud services (Huang, 2016), mobile instant messaging (Oghuma et al., 2016), Massive Open Online Courses (MOOC) (Alraimi et al., 2015; J. Zhou, 2017), mobile gaming wearable technology (Nascimento et al., 2018), travel apps (Choi et al., 2019), mobile communication applications (Wang et al., 2019), mobile banking services (Susanto et al., 2016; Foroughi et al., 2019; Rabaa’i and AlMaati, 2021), and desktop services (Huang, 2019). Figure 1 depicts the ECM.

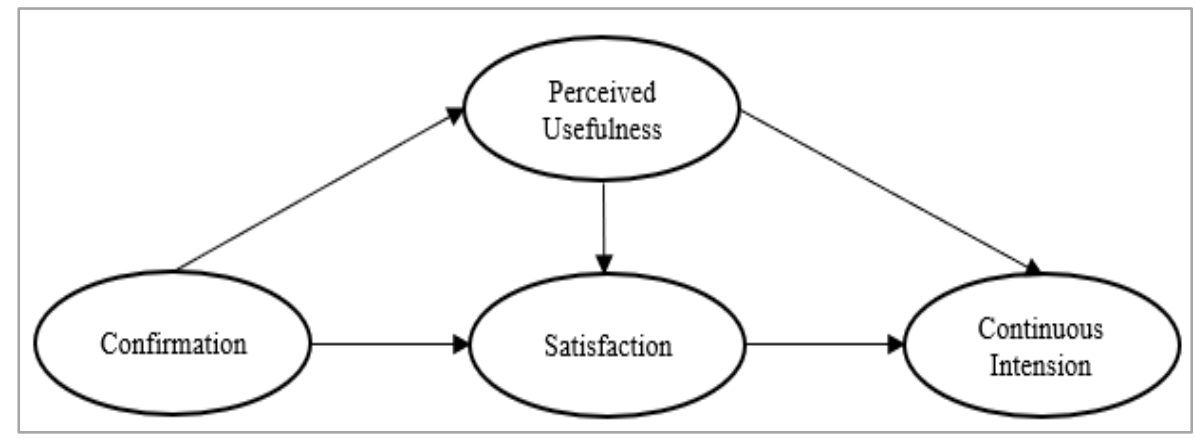

Figure 1. The ECM (Bhattacherjee, 2001a) 
The ECM is supported by four main constructs; namely, confirmation, perceived usefulness (or performance expectancy), are often interchangeable (Huang, 2019), satisfaction, and continuance intention (Bhattacherjee, 2001a). The confirmation construct refers to the degree to which a user's expectation of a particular technology is met by his/her experience of using it (Huang, 2016). Perceived usefulness refers to "the degree to which a person believes that using a particular system would enhance his or her job performance" (Davis, 1989, p. 320). Satisfaction refers to "a psychological or affective state related to and resulting from a cognitive appraisal of the expectation-performance discrepancy (confirmation)" (Bhattacherjee, 2001 a, p. 354). Based on a literature review of the expectation-confirmation model, Huang (2019, p. 25) stated that when users confirmed that a particular technology meets their expectations, they tend to believe that the technology will not only cost them minimal effort but also improve their performance, and therefore find it satisfactory. Then, when they find the technology effortless, they tend to believe that the technology will enhance their effectiveness, and they will have a sense of satisfaction about the technology and will continue using it as a result. Similarly, users will have a sense of satisfaction about a technology when they find it actually useful, and they will have the intention to continue using it. Finally, users' sense of satisfaction about a technology will encourage their intention to continue using it, and prompt them to act accordingly.

Confirmation $(\mathrm{CON})$ is defined as the extent to which a user perceives that their initial expectations are being confirmed during actual use (Rahi et al., 2018). Prior studies demonstrated the significant relationship between confirmation and performance expectancy, as well as satisfaction in various technology settings (e.g., Alraimi et al., 2015; P. Cheng et al., 2019; Foroughi et al., 2019; Fu et al., 2018; Hong et al., 2006; Huang, 2019; Kim \& Park, 2018). As such, we argue that when students confirmed that Moodle meet their expectations, they tend to believe that this system is beneficial, effective, convenient, and useful, and this, in turn, will promote their satisfaction toward Moodle. Hence, we hypothesize the following:

H1: Confirmation significantly influences performance expectancy.

H2: Confirmation significantly influences students' satisfaction with Moodle.

Performance expectancy (PE), similar to perceived usefulness and relative advantage (e.g., Alwahaishi \& Snásel, 2013; Huang, 2019; Teo, 2011; Venkatesh et al., 2003), refers to the extent to which the individual believes that usage of a particular technology will provide benefits to him/her in performing certain activities (Venkatesh et al., 2012). Venkatesh et al. (2003) argued that PE is found to be a stable variable to investigate user behavior, both initial and post-adoption stages. Hong et al. (2006) and Dia et al. (2020) reported that a user's perceived PE of a technology is a key determinant of satisfaction and continuance intention. Prior studies reported the significant positive effect of PE on satisfaction (e.g., Joo et al., 2016; Kim-Soon et al., 2017; Kumar et al., 2018; Lim et al., 2019), and continuous intention to use a technology (e.g., Foroughi et al., 2019; Gilani et al., 2017; Rabaai, 2015; Rabaai et al., 2015; Rabaa'i, 2016, 2017b; Rabaa'i and Zhu, 2021; Rabaa'i, in press; Shaw \& Sergueeva, 2019; B. Zogheib et al., 2015). Additionally, previous studies also confirmed the significant relationship between PE and users' attitude (e.g., Dai et al., 2020; Ding, 2019; Gasaymeh \& Waswas, 2019; Ifinedo, 2018; Sabah, 2019). Based on the above literature, we argue that the more students feel that Moodle is useful, convenient and beneficial for their learning, the greater: (1) they are satisfied with the system, (2) the likelihood that they will continue using Moodle, and (3) they will formulate a positive attitude toward the system. Accordingly, we posited the following hypotheses:

H3: Performance expectancy significantly influences students' satisfaction with Moodle.

H4: Performance expectancy significantly influences continuous intention to use Moodle.

H5: Performance expectancy significantly influences students' attitude towards Moodle.

Satisfaction (SAT) refers to "a psychological or affective state related to and resulting from a cognitive appraisal of the expectation-performance discrepancy (confirmation)" (Bhattacherjee, 2001a, p. 354). The ECM suggests users' satisfaction could be regarded as the most important factor that 
determines a user's intention for continuous use (e.g., Bhattacherjee, 2001a; Foroughi et al., 2019; Huang, 2019; Rahi et al., 2018; Susanto et al., 2016). Sabah (2019, p. 7) stated that satisfaction "is an evaluation of emotion associated with an affective attitude towards a system (i.e., whether the utilization experience is pleasurable as expected). Therefore, a user may have a positive attitude towards a system, but still feels dissatisfied after utilizing the system due to low expectation". According to Foroughi et al. (2019), the level of customers' satisfaction with a product or service could be the primary reason for making a repurchase decision, which is in fact the same concept as continuance intention towards using technology (Tran et al., 2019). Alraimi et al. (2015) and Y.-M. Cheng et al. (2014b) argued that users will have a sense of satisfaction about a particular technology and when they find it actually useful, they will have the intention to continue using it. Previous research has confirmed the significant relationship between satisfaction and continuous intention in different technological contexts (e.g., Alraimi et al., 2015; Alshurideh et al., 2020; Foroughi et al., 2019; Gilani et al., 2017; Hong et al., 2006; Joo et al., 2016; Rabaa'i et al., 2018; Sabah, 2019). Thus, we argue that the more satisfied students are with Moodle, the greater the likelihood that they will continue using the system. Consequently, the following hypothesis is proposed:

H6: Students' satisfaction significantly influences continuous intention to use Moodle.

This study aims at investigating students' continuance intention to use Moodle (as LMS) in the postadoption phase by extending the ECM. However, despite its strong theoretical foundation, "the ECM ... has been found to be parsimonious in explaining post-adoption dynamics" (Gupta et al., 2020). As such, researchers in different contexts have added various factors to better investigate users' continuance intention; for example, trust (Asnakew, 2020), perceived security and privacy (Susanto et al., 2016), attitude (Ding, 2019), effort expectancy (Foroughi et al., 2019), perceived value (Hsiao \& Chang, 2014), self-efficacy (M.-H. Hsu \& Chiu, 2004), and social norms (Kim, 2010). Our proposed model added system interactivity, effort expectancy, self-efficacy, computer anxiety, attitude, subjective norms, and facilitating conditions as crucial factors that are important to continue using Moodle. The research model is depicted in Figure 2.

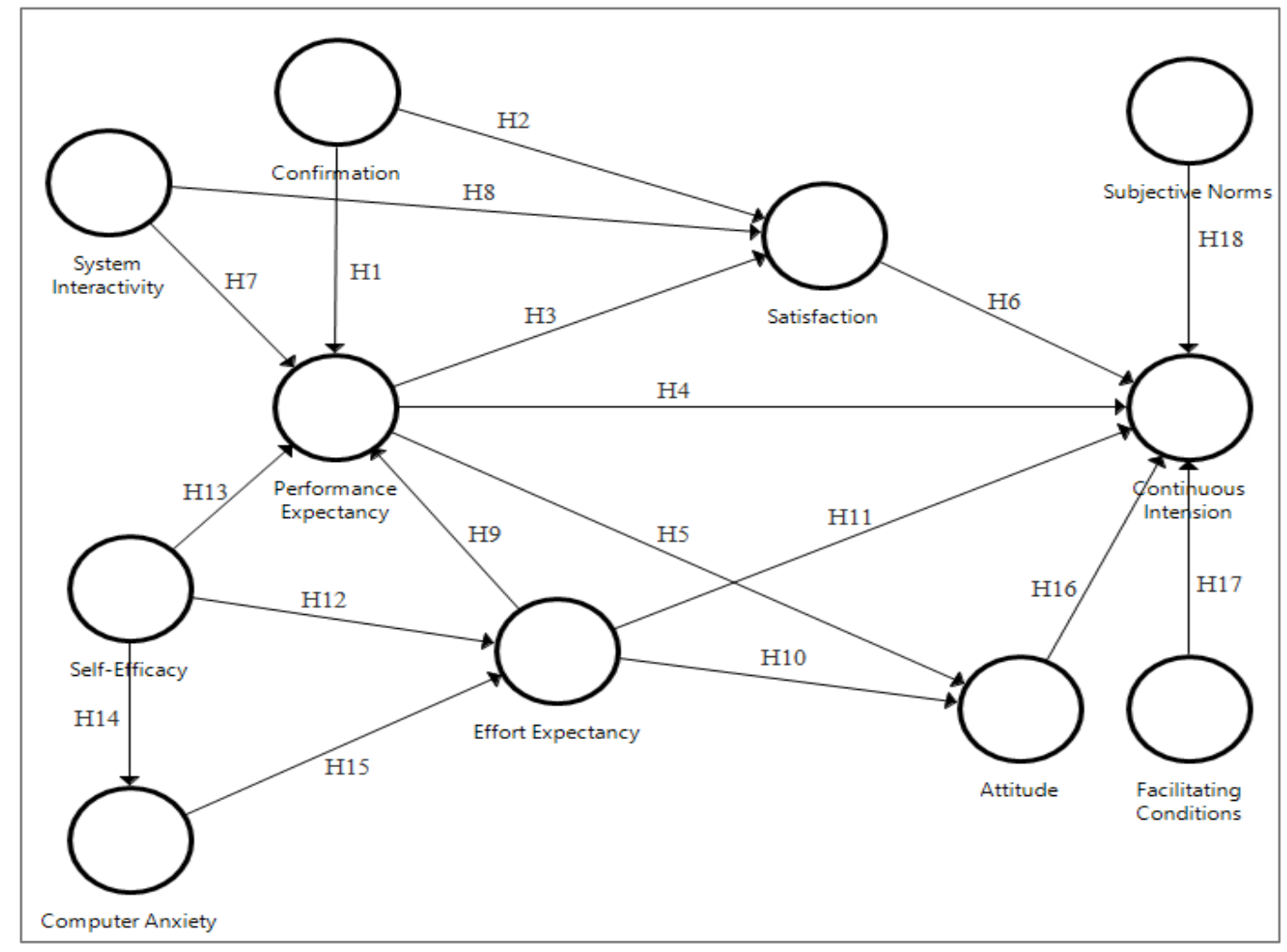

Figure 2. The research model 


\section{SYSTEM INTERACTIVITY (SIN)}

Systems interactivity (SIN) refers to the interactions between instructors and learners, and the collaboration in learning that results from these interactions (Pituch \& Lee, 2006). Bhuasiri et al. (2012) and Brown and Charlier (2013) have highlighted the importance of functionality characteristics as a critical success factor of LMS. Specifically, the availability of functionalities to support interactions among students and between instructors and students has been highlighted as essential to the learning process (Moreno et al., 2017). For instance, Daniela et al. (2019) argued that the key aspects of learning processes can be listed as the interactions between students, between students and teaching staff as well as the collaboration in learning from these interactions. The literature suggests different interactive mechanisms (e.g., a discussion room, instant messenger, message board, online chat room, or video conferencing) of the LMS to make students feel connected to others, and further make students' learning via the systems useful and boost their satisfaction with the LMS (e.g., Y.-M. Cheng, 2012; B.-C. Lee et al., 2009; Yoo et al., 2010).

In their literature review in the context of e-learning, Baki et al. (2018, p. 10) stated that increasing interaction results in higher motivation, boosts the level of satisfaction received from learning, causes a more optimistic view on learning, and triggers effective learning and success. For instance, Pituch and Lee (2006) postulated that students who think the LMS can be used to support effective interactions tend to believe the system can help them learn more effectively. Additionally, system interactivity can help students to be more confident and trained in the use of LMS platforms, enhance the learning process, and facilitate communication among the faculty, students, and peers (e.g., Huang et al., 2017; C. Lee et al., 2017). Many studies have found significant positive effect of system interactivity on perceived usefulness (i.e., performance expectancy) (e.g., Aldiab et al., 2017; Chmiel et al., 2017; Cidral et al., 2018; Hone \& El Said, 2016; Shin et al., 2011; M. Zhang et al., 2017) and on users' satisfaction (e.g., Arbaugh, 2002; Cidral et al., 2018; J. Sun \& Hsu, 2013; P.-C. Sun et al., 2008). As such, we argue that the higher the system interactivity, the stronger the students believe that the LMS is to be useful for their education and will increase their satisfaction with the system. According, the study posited the following hypotheses:

H7: System interactivity significantly influences performance expectancy.

H8: System interactivity significantly influences students' satisfaction with Moodle.

\section{EFFORT EXPECTANCY (EE)}

Effort expectancy (EE), similar to perceived ease of use (e.g., Huang, 2019; Teo, 2011; Venkatesh et al., 2003), is defined as the degree to which a person believes that using a particular system would be free of effort (Davis, 1989). It represents the extent of the ease associated with individuals' use of technology (Venkatesh et al., 2012), and it is related to the degree of information accessibility, flexibility, easiness to use, and clear interaction with the system (Sabah, 2019). Sanchez-Franco (2010) postulated that users tend to use an IS if they believe that it is easy to use. In this study, effort expectancy is used to measures students' perceived ease of use of Moodle. Hence, we argue that the easier the students believe Moodle to use, the higher their intention to continue using this LMS. Previous research has confirmed the significant relationship between effort expectancy and continuous intention in different technological contexts (e.g., Abdullah \& Ward, 2016; Alalwan et al., 2016, 2017, 2018; Almisad \& Alsalim, 2020; Alshurideh et al., 2020; Rabaai, 2015; Rabaai et al., 2015; Rabaa'i, 2016, 2017b; Sabah, 2019; Sharif et al., 2019; S. Zogheib et al., 2015). Further, we argue that if students perceived the use of Moodle needs less effort and is not difficult, they will form a positive attitude towards the systems and they perceive the use of this LMS as useful for their academic performance (Davis, 1989). Many studies have found significant positive effect of effort expectancy on performance expectancy (e.g., Alalwan et al., 2016, 2017, 2018; Alkhaldi \& Kharma, 2019; Alshurideh et al., 2020; Jaradat \& Al Rababaa, 2013; Joo et al., 2016; Rabaai et al., 2015), and on attitude (e.g., Abdullah 
\& Ward, 2016; Davis, 1989; Sabah, 2019; Wu \& Chen, 2017). Consequently, this study posited the following hypotheses:

H9: Effort expectancy significantly influences performance expectancy.

H10: Effort expectancy significantly influences students' attitude towards Moodle.

H11: Effort expectancy significantly influences continuous intention to use Moodle.

\section{SELF-EFFICACY (SEF)}

Venkatesh et al. (2003) defined self-efficacy as a judgment of one's ability to use a technology to accomplish a particular job or task. Further, Bandura (1994) discussed the influence of self-efficacy on an individual's thinking, motivation and behavioral intention. Self-efficacy may build one's ability to complete different tasks after learning how to perform activities. In fact, self-efficacy can control one's behavior, such as motivation, persistence, endurance, and diligence, to overcome the difficulties that may appear (Susanto et al., 2016, p. 512). In other words, self-efficacy refers to individuals' abilities and skills that they are cognizant of after first-time use, but before making a sensible decision about their continuance behavior (Foroughi et al., 2019). As a result, the concept of self-efficacy was linked to IS continuance intention and behavior (Bhattacherjee et al., 2008). Hence, self-efficacy beliefs might influence whether people decide to engage with technology and whether, and for how long, they try to solve a task and overcome problems (He \& Freeman, 2010). As such, people with high self-efficacy have high self-confidence on their skills and capabilities to carry out tasks, and this in turn will improve their perceptions towards the ease of use and usefulness of a particular IS (Sabah, 2019). In their comprehensive literature review, Baki et al. $(2018$, p. 9) stated that " 58 of the 71 publications that examine self-efficacy's level of influence on perceived ease of use for e-learning systems confirm the presence of a significant and positive relationship". Additionally, other previous studied also confirmed the positive influence of self-efficacy on the ease of use of a system (i.e., effort expectancy) and on systems' perceived usefulness (i.e., performance expectancy) (e.g., Alshurideh et al., 2020; Ifinedo, 2017; Rabaa'i, 2016; Rana \& Dwivedi, 2015; Sabah, 2019; Salloum et al., 2019; Wook et al., 2015; Zhao et al., 2008). Therefore, we argue that students with high self-efficacy are expected to perceive Moodle useful, convenient, easy to use, and are expected to make full use of the system to enhance their academic performance (Balakrishnan \& Gan, 2016). In contrast, students with low self-efficacy need a high level of support to compensate for their deficiency (Sabah, 2019), and do not perceive the systems to be useful and easy to use.

Further, the relationship between self-efficacy and computer anxiety was studied by H.-R. Chen and Tseng (2012) and Verkijika (2020). Prior research has highlighted the negative influence of self-efficacy on computer anxiety (e.g., Alenezi et al., 2010; Jashapara \& Tai, 2011; Sabah, 2019; Verkijika, 2020; Wook et al., 2015). Self-efficacy is associated with anxiety, such that individuals with a high level of self-efficacy in a given domain will have lower levels of anxiety when it comes to engaging in behaviors associated with the domain (e.g., Compeau \& Higgins, 1995; Qudsyi \& Putri, 2016; Verkijika, 2020). In other words, the negative effect of self-efficacy on computer anxiety implies that students have more self-confidence in their capabilities to continue using Moodle. Based on the above literature, we posited the following hypotheses:

H12: Self-efficacy has a significant positive effect on effort expectancy.

H13: Self-efficacy has a significant positive effect on performance expectancy.

H14: Self-efficacy has a significant negative effect on anxiety.

\section{COMPUTER ANXIETY (CAX)}

While technology is considered as a factor for satisfaction, users' incapability of dealing with technology tools efficiently may evoke users' anxiety and encourage a negative affective response towards 
using technology (Sabah, 2019). Computer anxiety is defined as "the tendency of individuals to be uneasy, apprehensive, or fearful about current or future use of computers" (Stewart \& Segars, 2002, p. 44). For instance, when dealing with information systems, anxiety is generally seen as the degree of apprehension that a person associates with the expected or actual use of the system (P. Zhang, 2013). That is, the concept of anxiety in the social cognitive theory (SCT) (Bandura, 1977) recognizes the role of emotions in influencing behavior, as anxiety is generally seen as a negative emotion (e.g., Beaudry \& Pinsonneault, 2010; Partala \& Saari, 2015; Rana \& Dwivedi, 2015; Rodger \& Gonzalez, 2014; Verkijika, 2020; P. Zhang, 2013). Bailey et al. (2017) argued that users who have anxious responses when using a particular information system, often have a strong fear or apprehension towards using the system and will, therefore, prefer to refrain from using it. If an individual gets anxious upon his/her usage of information technologies, he/she might perceive the system as complicated and difficult (van Raaij \& Schepers, 2008). As such, inducing high levels of anxiety regarding a given technology will directly or indirectly result in lower intentions to continue using the system (AlFraihat et al., 2020). Previous studies have highlighted the importance of computer anxiety by demonstrating its negative influence on perceived ease of use (e.g., Abdous, 2019; Abdullah \& Ward, 2016; Bailey et al., 2017; Baki et al., 2018; Dönmez-Turan \& Kır, 2019; Park et al., 2019; Sabah, 2019). For example, in a digital library context, Nov and Ye (2009) argued the negative relationship between perception of ease of use of the system and users' computer anxiety. Guo et al. (2013) studied mobile health services in China and reported a negative effect of computer anxiety on perceived ease of use and perceived usefulness. Similar results were reported in a mobile shopping context (Saprikis et al., 2018). Also, Bailey et al. (2017) found that US users' perceptions towards the ease of use of mobile payments are negatively influenced by computer anxiety. Additionally, in the e-learning context, Abdullah and Ward (2016) demonstrated how computer anxiety negatively affect users' perceptions towards the ease of use of the systems. In a study concerning the motivational factors and barriers to the continuous use of blended learning approach using Moodle, Sabah (2019) reported the same negative effect of computer anxiety on ease of use. Similar results concerning the negative effect of computer anxiety on ease of use were also reported in a statistical software context (M. K. Hsu et al., 2009), and different learning systems (e.g., Baki et al., 2018; Faham \& Asghari, 2019; Ifinedo, 2017). Accordingly, the following hypothesis is proposed:

H15: Computer anxiety is negatively associated with effort expectancy.

\section{ATTITUDE}

Being the most immediate antecedent of continued use intention in the ECM, Bhattacharjee (2001a) argued that the satisfaction construct plays the same role as the attitude (ATT) in the Technology Acceptance Model (TAM). The only distinction between them is the time of measurement. Attitude is a pre-acceptance construct whereas satisfaction is a post-acceptance construct (Dai et al., 2020). For instance, Wixom and Todd (2005) assumed that although both satisfaction and attitude are affect variables, satisfaction is an emotional response to a use experience, whereas attitude is an affective reaction to behavior. Further, Dia et al. (2020) postulated that satisfaction pertains to the overall feeling about a past use experience, whereas attitude is related to feelings about future use. While the ECM focusses on confirmation, perceived usefulness and satisfaction in explaining continuance intention, users' continuance intention is not only determined by their perceptions and satisfaction but also by attitude (Foroughi et al., 2019). For instance, the cognitive model (COGM) proposed that continuance behavioral intention should be defined as a function of both satisfaction and attitude (Oliver, 1980). As a result, many researchers (e.g., Al-Emran et al., 2020; Dai et al., 2020; Ding, 2019; Sabah, 2019; Wixom \& Todd, 2005) considered satisfaction and attitude to be two conceptually and theoretically different constructs. In line with Dia et al. (2020), this study includes both constructs in the proposed model, as satisfaction represents the affect from past use experience of Moodle and attitude captures the anticipatory affect related to future use of Moodle. Previous studies pointed out that attitude has a significant association with continuous intention to use an IS (e.g., Gasaymeh \& Waswas, 
2019; Ifinedo, 2017, 2018; Sabah, 2019; J. Zhou, 2017). Therefore, we propose the following hypothesis:

H16: Students' attitude significantly influence continuous intention to use Moodle

\section{FACILITATING CONDITIONS (FC)}

Facilitating conditions (FC), similar to perceived behavioral control in the theory of planned behavior (TPB) (Boonsiritomachai \& Pitchayadejanant, 2017), means that users possess the required resources and expertise to use a given technology (Y. Cheng et al., 2020). Further, FC refers to the extent to which individuals believe that both technical and organizational infrastructure exist to support the use of a particular technology (Venkatesh et al., 2003), and it reflects an individual's perceptions about his/her control over a behavior (Venkatesh et al., 2008). Iqbal and Qureshi (2012) argued that students face several technical challenges when they use LMS, such as limited processing speed, low bandwidth, unfriendly user interface, and fewer surf-ability, compatibility issues. While the availability of proper facilitating conditions (e.g., training courses, technical support, and adequate resources) is crucial for continuous intention to use a particular technology (Aypay et al., 2012), the absence of facilitating conditions could lead to a negative impact on IT usage and behavioral intentions, as the absence of facilitating resources generates obstacles to usage, or could encourage the formation of negative behavioral intentions towards usage (Al-Adwan et al., 2018). For instance, according to Nysveen and Pedersen (2016), users who have access to a favorable set of facilitating conditions are more likely to have a greater intention to use a technology. In this study, FC reflects the effect of resources availability, internet accessibility, compatibility with other smart devices, such as mobile phones and tablets, and required knowledge, as well as skills to use the LMS (i.e., Moodle). Accordingly, a hypothesis is presented as follows:

H17: Facilitating conditions significantly influence continuous intention to use Moodle

\section{SUBJECTIVE NORMS (SN)}

Subjective norms $(\mathrm{SN})$, one of the social influence variables, is defined as "the perceived social pressure to perform or not to perform the behavior" (Ajzen, 1991). SN refers to the person's perception that most people who are important to him/her think he/she should or should not perform the behavior in question (Davis, 1989). Venkatesh et al. (2003) argued that, whether this is positive or negative, $\mathrm{SN}$ is a very important factor in many aspects of the lives of citizens and is likely to be influential. For instance, it is believed that, in some cases, people might use a system to comply with the mandates of others rather than their own feelings and beliefs (Davis, 1989). Further, studies related to social influence theory identified subjective norms as one of the most important factors that influence the use of a particular technology. Opinions from important people to the users (e.g., team leaders, instructors, colleagues, family) will influence their intention to continue using a specific technology (e.g., Huang, 2016; Salloum et al., 2019; T. Zhou et al., 2010). In this study, SN includes the influences of instructors, colleagues, and people who are important to students. Previous studies pointed out that subjective norms have a significant effect on continuous intention (e.g., Al-Emran et al., 2020; Dalvi-Esfahani et al., 2018; Huang, 2019; Sabah, 2019). Accordingly, the following hypothesis is suggested:

H18: Subjective norms significantly influence continuous intention to use Moodle

\section{METHODOLOGY}

An empirical study was conducted with an objective to test the relationships between the constructs of the conceptual model depicted in Figure 2. To achieve this objective and to test the research hypotheses, a survey-based study was employed to collect the needed empirical data. This section describes the measurement items, data collection, and the study sample. 


\section{MEASUREMENT ITEMS}

To obtain the needed empirical data and to ensure validity and reliability, all items used to measure the constructs are adapted from existing literature, with slight wording modifications to fit the study context. In total, 37 measurement items have been used. Table 1 shows the constructs, the measurement items for each construct, and the sources from where these items were adapted. Each item, except for the Satisfaction construct measurement items, was measured with a seven-point Likert scale, ranging from "strongly disagree" (1) to "strongly agree" (7). The Satisfaction construct adopted, based on Spreng et al.'s (1996) dimensions, has been validated in the IS context (e.g., Bhattacherjee, 2001a; Bhattacherjee \& Premkumar, 2004; Premkumar \& Bhattacherjee, 2008; Rabaa'i, 2012; Rabaa'i et al., 2015; Rabaa'i, 2017b). This construct captures respondents' satisfaction levels both in intensity and direction (Oliver, 1997) along 7-point scales anchored between four semantic differential adjective pairs: "frustrated/contented," "displeased/pleased," "terrible/delighted," and "dissatisfied/satisfied" (Bhattacherjee, 2001a).

Table 1. The constructs, the measurement items and the sources

\begin{tabular}{|c|c|c|}
\hline Construct & Measurement Items & Reference \\
\hline $\begin{array}{l}\text { Confirmation } \\
(\mathrm{CON})\end{array}$ & $\begin{array}{l}\text { CON1: My experience with Moodle was better than what I } \\
\text { had expected } \\
\text { CON2: Moodle service level provided by the university was } \\
\text { better than what I had expected } \\
\text { CON3: The expectations that I have about Moodle were cor- } \\
\text { rect } \\
\text { CON4: Overall, most of my expectations from using Moodle } \\
\text { were confirmed }\end{array}$ & $\begin{array}{l}\text { Bhattacherjee (2001a); } \\
\text { Susanto et al., (2016) }\end{array}$ \\
\hline $\begin{array}{l}\text { Performance } \\
\text { Expectancy } \\
(\mathrm{PE})\end{array}$ & $\begin{array}{l}\text { PE1: I find Moodle useful in my daily life as a student. } \\
\text { PE2: Using Moodle increases my chances of achieving things } \\
\text { that are important to me. } \\
\text { PE3: Using Moodle helps me accomplish things more } \\
\text { quickly. } \\
\text { PE4: Using Moodle increases my productivity. }\end{array}$ & Venkatesh et al. (2012) \\
\hline $\begin{array}{l}\text { Satisfaction } \\
\text { (SAT) }\end{array}$ & $\begin{array}{l}\text { SAT1: frustrated/contented } \\
\text { SAT2: displeased/pleased } \\
\text { SAT3: dissatisfied/satisfied }\end{array}$ & $\begin{array}{l}\text { Bhattacherjee (2001a); } \\
\text { Rabaa'i (2012); Rabaa'i } \\
\text { et al., (2015); Rabaa'i } \\
\text { (2017a, 2017b) }\end{array}$ \\
\hline $\begin{array}{l}\text { System } \\
\text { Interactivity } \\
\text { (SIN) }\end{array}$ & $\begin{array}{l}\text { SIN1: Moodle enables interactive communication among } \\
\text { learners. } \\
\text { SIN2: Moodle enables interactive communication between } \\
\text { the instructor and learners. } \\
\text { SIN3: The communicational tools in Moodle are effective }\end{array}$ & Y.-M. Cheng (2012) \\
\hline $\begin{array}{l}\text { Effort } \\
\text { Expectancy } \\
(\text { EE) }\end{array}$ & $\begin{array}{l}\text { EE1: Learning how to use Moodle is easy for me. } \\
\text { EE2: My interaction with Moodle is clear and understanda- } \\
\text { ble. } \\
\text { EE3: I find Moodle easy to use. } \\
\text { EE4: It is easy for me to become skillful at using Moodle }\end{array}$ & Venkatesh et al. (2012) \\
\hline $\begin{array}{l}\text { Self-Efficacy } \\
\text { (SEF) }\end{array}$ & $\begin{array}{l}\text { SEF1: I can perform my studies using Moodle even if there is } \\
\text { no one around to help me } \\
\text { SEF2: I can perform my studies using Moodle with only a } \\
\text { simple manual or online help for reference } \\
\text { SEF3: I am confident enough in my ability to perform my } \\
\text { studies' needs using Moodle }\end{array}$ & $\begin{array}{l}\text { Bhattacherjee (2001a); } \\
\text { Suh and Han (2002); } \\
\text { Susanto et al., (2016) }\end{array}$ \\
\hline $\begin{array}{l}\text { Computer } \\
\text { Anxiety } \\
\text { (CAX) }\end{array}$ & $\begin{array}{l}\text { CAX1: I feel anxious about using Moodle. } \\
\text { CAX2: I hesitate to use Moodle for fear of failure and self- } \\
\text { degrading. }\end{array}$ & Sabah (2019) \\
\hline
\end{tabular}




\begin{tabular}{|c|c|c|}
\hline Construct & Measurement Items & Reference \\
\hline & $\begin{array}{l}\text { CAX3: I hesitate to use Moodle for fear of making mistakes I } \\
\text { cannot correct. } \\
\text { CAX4: Moodle is somewhat intimidating to me }\end{array}$ & \\
\hline $\begin{array}{l}\text { Attitude } \\
\text { (ATT) }\end{array}$ & $\begin{array}{l}\text { ATT1: I like my study more when I use Moodle. } \\
\text { ATT2: Using Moodle in my study is a pleasant experience. } \\
\text { ATT3: Using Moodle in my study is a wise idea }\end{array}$ & $\begin{array}{l}\text { Davis (1989); Cheon et } \\
\text { al. (2012); }\end{array}$ \\
\hline $\begin{array}{l}\text { Subjective } \\
\text { Norms } \\
\text { (SN) }\end{array}$ & $\begin{array}{l}\text { SN1: My instructors recommend and support the use of } \\
\text { Moodle. } \\
\text { SN2: My colleagues think that I should use Moodle. } \\
\text { SN3: People who are important to me think that I should use } \\
\text { Moodle. }\end{array}$ & $\begin{array}{l}\text { Cheon et al. (2012); } \\
\text { Taylor and Todd (1995) }\end{array}$ \\
\hline $\begin{array}{l}\text { Facilitating } \\
\text { Conditions } \\
\text { (FC) }\end{array}$ & $\begin{array}{l}\text { FC1: I have the resources necessary to use Moodle } \\
\text { FC2: I have the knowledge and skills necessary to use Moodle } \\
\text { FC3: Moodle is compatible with other technologies I use }\end{array}$ & Venkatesh et al. (2012) \\
\hline $\begin{array}{l}\text { Continuous } \\
\text { Intention } \\
\text { (CI) }\end{array}$ & $\begin{array}{l}\text { CI1: I intend to continue using Moodle in the future. } \\
\text { CI2: I will always try to use Moodle in my daily life as a stu- } \\
\text { dent } \\
\text { CI3: I will keep using Moodle as regularly as I do now }\end{array}$ & Bhattacherjee (2001a) \\
\hline
\end{tabular}

A pre-test and pilot test were employed. In the pre-test, three expert academics were involved to verify the measurement scales, assess the suitability, relevance, readability of the questionnaire, and discuss possible changes to be implemented in the questions to clarify any ambiguity of the questionnaire. Then, to ensure the adequacy as well as reliability of the measures and to avoid any confusion or misinterpretations of the survey questions, a pilot study was conducted before the main study. Thirty-five questionnaires were used for the pilot study. The questionnaires were given to senior students at a private American University in the State of Kuwait, who were asked to complete the given questionnaire and provide any comments or concerns about it. Twenty-two questionnaires were returned. Noticeably, all respondents indicated that the questionnaire is easy, clear and did not required much time to be filled. Minor revisions of the survey questionnaire resulted from the completed pilot study. Cronbach's alpha was used to check the reliability of the constructs' scale used. Values for all constructs were higher than 0.70 as suggested by Nunnally and Bernstein (1994).

\section{DATA COLLECTION}

A questionnaire was employed to collect data from students at a private American university in the State of Kuwait between May and June 2019. Both paper-based and online questionnaires were developed and distributed. The items in both survey questionnaires were in the English language only, as English is the teaching language in the selected institution for this study. Students were invited to take part of this study through face-to-face invitation from the members of this research team. An explanation of the study objectives was presented. Students were informed that participation in this study was voluntary, and no rewards or incentives were offered. Participants were also notified of their rights to withdraw from this study whenever they wanted.

\section{THE STUDY SAMPLE}

Since the population size is unknown for this study, a convenient sampling method was adopted (Liébana-Cabanillas et al., 2018; San Martín \& Herrero, 2012; Sharma et al., 2019). Moreover, as suggested by Liébana-Cabanillas et al. (2018), San Martín and Herrero (2012), and Sharma et al. (2019), the quota sampling method was conducted to match the target population structure in both age and gender. A total of 431 questionnaires were collected. Of the submitted questionnaires, 44 were excluded because of incomplete answers, leaving 387 usable survey responses. SPSS 20 was used to perform the descriptive statistical analysis. Of the respondents, 49 percent are males while 51 percent are females. Table 2 represents the demographic information of the participants. 
Table 2. Demographic information of the participants

\begin{tabular}{lll}
\hline Data & Frequency & Percentage (\%) \\
\hline Gender & & \\
Male & 190 & 49 \\
Female & 197 & 51 \\
Total & 387 & 100 \\
\hline Age & & \\
Less than 18 years & 170 & 44 \\
18-25 years & 118 & 30 \\
26-30 years & 76 & 20 \\
More than 30 years & 23 & 6 \\
Total & 387 & 100 \\
\hline Moodle usage & & \\
Less than a year & 48 & 12 \\
1-2 years & 166 & 43 \\
3-4 years & 122 & 32 \\
more than 4 years & 51 & 13 \\
Total & 387 & 100 \\
\hline Major of study & & \\
CS and IS & 52 & 13 \\
Engineering & 175 & 45 \\
Business & 105 & 27 \\
Other & 55 & 14 \\
Total & 387 & 100 \\
\hline Weekly usage of Moodle & & 8 \\
Once a week & 31 & 58 \\
2-3 times a week & 226 & 25 \\
4-5 times a week & 98 & 100 \\
more than 5 times a week & 32 & \\
Total & 387 & \\
\hline
\end{tabular}

Of the respondents, 44 percent were aged less than 18 years; 30 percent were aged 18-25, 20 percent were aged 26-30 years; and only 6 percent were older than 30 years of age. As for the respondents' experience with Moodle usage, 32 percent of the respondents have been using Moodle for 3-4 years, 13 percent for more than 4 years, 12 percent for less than a year, and only 3 percent have been using Moodle for 1-2 years. Also, students were from different academic majors: computer science (CS) and information systems (IS) 13 percent, engineering 45 percent, business 27 percent, while 14 percent of the respondents were studying other majors. As for the respondents' experience in using Moodle, about 8 percent have been using Moodle once a week, 58 percent have been using Moodle between 2-3 times a week, 25 percent between 4-5 times a week, and only 8 percent have been using Moodle for more than 5 times a week.

\section{RESULTS}

The research model presented in Figure 2 was analyzed using SmartPLS 3.2.9 (Ringle et al., 2015), a software that relies on the partial least squares structural equation modelling (PLS-SEM) technique. Hair, Hult, et al. (2017) suggested that the first phase in PLS-SEM is to specify a path model that connects the measurement items with the constructs. The model specification is concerned with setting up the outer (i.e., measurement) model and the inner (i.e., structural) model. The outer model presents the relationships between the measurement items and constructs, while the inner model presents the relationships between the constructs. Figure 3 presents the model specification (measurement and structural models) of this study. 


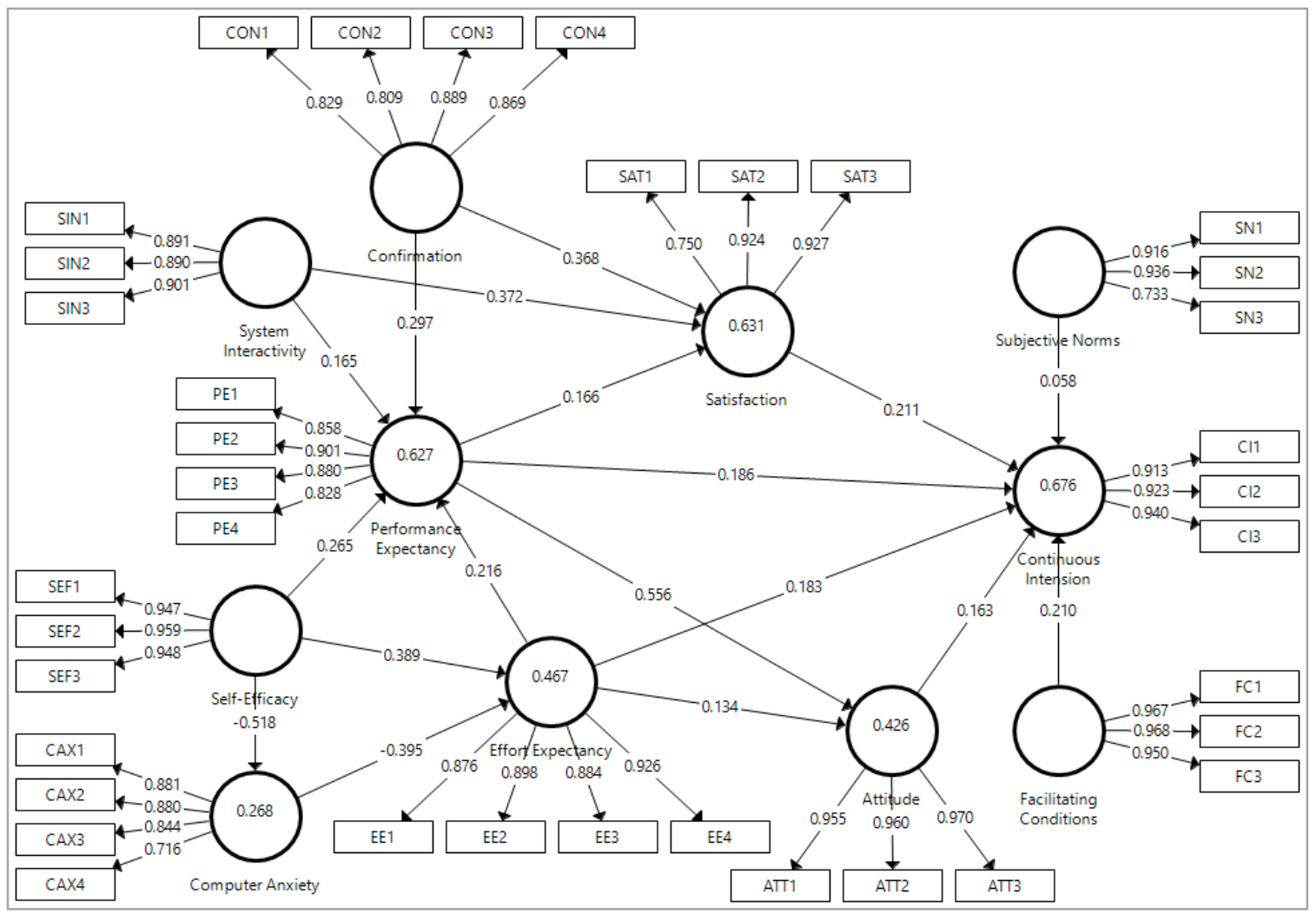

Figure 3. The measurement and structural models

After specifying the research model, Hair, Hollingsworth, et al. (2017) and Hair, Hult, et al. (2017) recommend the validation of the model by assessing the outer (i.e., measurement) model then assessing the inner (i.e., structural) model.

\section{MEASUREMENT MODEL}

Hair, Hollingsworth et al. (2017) argued that both reliability and validity have to be verified during measurement model assessment. Measurement model reliability is measured by utilizing both Cronbach's alpha (CA) and composite reliability (CR) (Hair, Hollingsworth, et al., 2017). Table 3 shows that the CA and CR values for all the latent variables are above the threshold measurement of 0.7 (Henseler et al., 2009, 2015).

Table 3. Items loading, significance level, Cronbach's alpha, composite reliability, and AVE

\begin{tabular}{llllll}
\hline Items & Loading & p-value & $\begin{array}{l}\text { Cronbach's } \\
\text { Alpha }\end{array}$ & $\begin{array}{l}\text { Composite } \\
\text { Reliability }\end{array}$ & AVE \\
\hline Confirmation (CON) & & & 0.871 & 0.912 & 0.722 \\
CON1 & 0.829 & 0.000 & & & \\
CON2 & 0.809 & 0.000 & & & \\
CON3 & 0.889 & 0.000 & & & \\
CON4 & 0.869 & 0.000 & & 0.799 \\
\hline Systems Interactivity (SIN) & & & 0.874 & & \\
SIN1 & 0.891 & 0.000 & & & \\
SIN2 & 0.890 & 0.000 & & & \\
SIN3 & 0.901 & 0.000 & & &
\end{tabular}




\begin{tabular}{|c|c|c|c|c|c|}
\hline Items & Loading & p-value & $\begin{array}{l}\text { Cronbach's } \\
\text { Alpha }\end{array}$ & $\begin{array}{l}\text { Composite } \\
\text { Reliability }\end{array}$ & AVE \\
\hline Performance Expectancy (PE & & & 0.890 & 0.924 & 0.752 \\
\hline PE1 & 0.858 & 0.000 & & & \\
\hline PE2 & 0.901 & 0.000 & & & \\
\hline PE3 & 0.880 & 0.000 & & & \\
\hline PE4 & 0.828 & 0.000 & & & \\
\hline Satisfaction (SAT) & & & 0.835 & 0.906 & 0.759 \\
\hline SAT1 & 0.750 & 0.000 & & & \\
\hline SAT2 & 0.924 & 0.000 & & & \\
\hline SAT3 & 0.927 & 0.000 & & & \\
\hline Effort Expectancy (EE) & & & 0.918 & 0.944 & 0.803 \\
\hline EE1 & 0.876 & 0.000 & & & \\
\hline EE2 & 0.898 & 0.000 & & & \\
\hline EE3 & 0.884 & 0.000 & & & \\
\hline EE4 & 0.926 & 0.000 & & & \\
\hline Self-Efficacy (SEF) & & & 0.948 & 0.966 & 0.905 \\
\hline SE1 & 0.947 & 0.000 & & & \\
\hline SE2 & 0.959 & 0.000 & & & \\
\hline SE3 & 0.948 & 0.000 & & & \\
\hline Computer Anxiety (CAX) & & & 0.850 & 0.900 & 0.694 \\
\hline CAX1 & 0.881 & 0.000 & & & \\
\hline CAX2 & 0.880 & 0.000 & & & \\
\hline CAX3 & 0.844 & 0.000 & & & \\
\hline CAX4 & 0.716 & 0.000 & & & \\
\hline Attitude (ATT) & & & 0.959 & 0.974 & 0.925 \\
\hline ATT1 & 0.955 & 0.000 & & & \\
\hline ATT2 & 0.960 & 0.000 & & & \\
\hline ATT3 & 0.970 & 0.000 & & & \\
\hline Subjective Norms (SN) & & & 0.833 & 0.899 & 0.751 \\
\hline SN1 & 0.916 & 0.000 & & & \\
\hline SN2 & 0.936 & 0.000 & & & \\
\hline SN3 & 0.733 & 0.000 & & & \\
\hline Facilitating Conditions (FC) & & & 0.959 & 0.971 & 0.925 \\
\hline FC1 & 0.967 & 0.000 & & & \\
\hline FC2 & 0.968 & 0.000 & & & \\
\hline FC3 & 0.950 & 0.000 & & & \\
\hline Continuous Intention (CI) & & & 0.912 & 0.948 & 0.856 \\
\hline CI1 & 0.913 & 0.000 & & & \\
\hline $\mathrm{CI} 2$ & 0.923 & 0.000 & & & \\
\hline $\mathrm{CI} 3$ & 0.940 & 0.000 & & & \\
\hline
\end{tabular}

Measurement model validity is evaluated by assessing convergent validity and discriminant validity. Henseler et al. (2009, p. 299) argued that convergent validity is established when "a set of indicators represents one and the same underlying construct". The convergent validity was assessed using the average variance extracted (AVE) and factor loadings. The AVE should be at least 0.50 and above (Hair, Hult et al., 2017; Henseler et al., 2015). The loadings of all measurement items (i.e., indicators) should be 0.50 or above on their hypothesized construct and they should be significant $(\mathrm{p}<0.05)$ (Hair, Hollingsworth et al., 2017). These two criteria have been fulfilled as shown in Table 3.

Discriminant validity refers to "the extent to which a construct is empirically distinct from other constructs in the path model" (Sarstedt et al., 2014, p. 108), and can be assessed by the Fornell and 
Larcker (1981) criterion. The Fornell and Larcker (1981) criterion requires constructs' AVE values to be greater than the squared inter-construct correlations. As seen in Table 4, when comparing the square roots of the AVE values with the other values on each column, the square roots of the AVE values for each latent variable are greater than any correlation relating to each latent variable.

Table 4. Fornell and Larcker discriminant validity criterion

\begin{tabular}{|l|lllllllllll|}
\hline & ATT & CAX & CON & CI & EE & FC & PE & SAT & SEF & SN & SIN \\
\hline ATT & 0.962 & & & & & & & & & & \\
CAX & -0.534 & 0.833 & & & & & & & & & \\
CON & 0.617 & -0.678 & 0.850 & & & & & & & & \\
CI & 0.651 & -0.637 & 0.775 & 0.925 & & & & & & & \\
EE & 0.502 & -0.597 & 0.614 & 0.659 & 0.896 & & & & & & \\
FC & 0.664 & -0.523 & 0.633 & 0.706 & 0.599 & 0.962 & & & & & \\
PE & 0.645 & -0.58 & 0.697 & 0.715 & 0.663 & 0.678 & 0.867 & & & & \\
SAT & 0.522 & -0.621 & 0.713 & 0.673 & 0.596 & 0.594 & 0.652 & 0.871 & & & \\
SEF & 0.616 & -0.518 & 0.623 & 0.613 & 0.593 & 0.623 & 0.659 & 0.524 & 0.952 & & \\
SN & 0.462 & -0.419 & 0.404 & 0.441 & 0.337 & 0.457 & 0.384 & 0.371 & 0.363 & 0.867 & \\
SIN & 0.474 & -0.639 & 0.614 & 0.631 & 0.645 & 0.552 & 0.616 & 0.701 & 0.487 & 0.338 & 0.894 \\
\hline
\end{tabular}

As Fornell and Larcker criterion overstate the presence of discriminant validity, Henseler et al. (2015) recommended the use of the Heterotrait-Monotrait (HTMT) criterion to test the discriminant validity. Using a Monte Carlo simulation study, Henseler et al. (2015) found that HTMT is able to achieve higher specificity and sensitivity rates ( $97 \%$ to $99 \%$ ) compared to the Fornell-Lacker (20.82\%), the most commonly used method to assess discriminant validity. The results shown in Table 5 demonstrate that all the HTMT values were lower than the recommended threshold of 0.90 (e.g., Gold et al., 2001; Grewal et al., 2004; Hair, Hollingsworth et al., 2017; Teo et al., 2008; Voorhees et al., 2016). Hence, the criterion for discriminant validity was achieved.

Table 5. Hetrotrait-Monotrait ratio (HTMT) test

\begin{tabular}{|l|lllllllllll|}
\hline & ATT & CAX & CON & CI & EE & FC & PE & SAT & SEF & SN & SIN \\
\hline ATT & & & & & & & & & & & \\
CAX & 0.593 & & & & & & & & & & \\
CON & 0.672 & 0.786 & & & & & & & & & \\
CI & 0.695 & 0.723 & 0.862 & & & & & & & & \\
EE & 0.535 & 0.673 & 0.684 & 0.717 & & & & & & & \\
FC & 0.691 & 0.579 & 0.693 & 0.752 & 0.639 & & & & & & \\
PE & 0.695 & 0.666 & 0.786 & 0.788 & 0.734 & 0.732 & & & & & \\
SAT & 0.589 & 0.739 & 0.832 & 0.770 & 0.682 & 0.667 & 0.757 & & & & \\
SEF & 0.645 & 0.576 & 0.682 & 0.658 & 0.635 & 0.653 & 0.716 & 0.595 & & & \\
SN & 0.515 & 0.513 & 0.482 & 0.493 & 0.379 & 0.506 & 0.441 & 0.454 & 0.405 & & \\
SIN & 0.515 & 0.739 & 0.700 & 0.702 & 0.719 & 0.601 & 0.699 & 0.817 & 0.532 & 0.404 & \\
\hline
\end{tabular}

\section{STRUCTURAL MODEL}

After ensuring the reliability and validity of the measurement model, the structure model is then assessed (Hair, Hollingsworth et al., 2017; Henseler et al., 2009, 2015). As suggested in SEM literature (e.g., Chin, 2010; Hair, Hollingsworth et al., 2017; Hair, Hult et al., 2017; Henseler et al., 2009, 2015; Rabaa'i, 2017a), the assessment of the structural model entails estimates for path coefficients $(\beta)$, determination of coefficient $\left(R^{2}\right)$, predictive relevance $\left(Q^{2}\right)$, and estimates for total effects $\left(f^{2}\right)$ and $\left(q^{2}\right)$.

The first step in assessing the structural model, using PLS, should be based on the path coefficient's $(\beta)$ direction algebraic sign, magnitude, and significance (e.g., Chin, 2010; Hair, Hult, et al., 2017; Henseler et al., 2009). In PLS, the individual path coefficients of the structural model can be 
interpreted as standardized beta coefficients of ordinary least squares regressions (Henseler et al., 2009 , p. 304). Path coefficients should exceed 0.100 to account for a certain impact within the structural model (Urbach and Ahlemann, 2010). Furthermore, path coefficients should be significant at least at the 0.050 level (Henseler et al., 2009; Urbach and Ahlemann, 2010). A consistent bootstrapping process with 5,000 samples was employed to examine the significance levels of path coefficients (Hair, Hollingsworth et al., 2017; Hair, Hult, et al., 2017). Table 6 presents the path coefficient, t-statistics, and p-values for the proposed hypothesis. The path coefficient provides the significance of the hypothesized relations connecting the constructs. Table 6 reveals that all hypotheses, except H18, were supported.

Table 6. Hypotheses' path coefficients, t-statistics and p-values

\begin{tabular}{|c|c|c|c|c|c|}
\hline & $\begin{array}{c}\text { Hypothesis } \\
\text { number }\end{array}$ & $\begin{array}{c}\text { Path } \\
\text { coefficient }\end{array}$ & t-statistics & p-values & Supported \\
\hline $\mathrm{CON} \rightarrow \mathrm{PE}$ & H1 & 0.297 & 4.801 & 0.000 & Yes \\
\hline $\mathrm{CON} \rightarrow \mathrm{SAT}$ & $\mathrm{H} 2$ & 0.368 & 5.525 & 0.000 & Yes \\
\hline $\mathrm{PE} \rightarrow \mathrm{SAT}$ & $\mathrm{H} 3$ & 0.166 & 3.070 & 0.002 & Yes \\
\hline $\mathrm{PE} \rightarrow \mathrm{CI}$ & $\mathrm{H} 4$ & 0.186 & 3.306 & 0.001 & Yes \\
\hline $\mathrm{PE} \rightarrow \mathrm{ATT}$ & H5 & 0.556 & 9.923 & 0.000 & Yes \\
\hline $\mathrm{SAT} \rightarrow \mathrm{CI}$ & H6 & 0.211 & 3.651 & 0.000 & Yes \\
\hline $\mathrm{SIN} \rightarrow \mathrm{PE}$ & $\mathrm{H} 7$ & 0.165 & 3.120 & 0.002 & Yes \\
\hline $\mathrm{SIN} \rightarrow \mathrm{SAT}$ & H8 & 0.372 & 5.819 & 0.000 & Yes \\
\hline $\mathrm{EE} \rightarrow \mathrm{PE}$ & H9 & 0.216 & 3.602 & 0.000 & Yes \\
\hline $\mathrm{EE} \rightarrow \mathrm{ATT}$ & $\mathrm{H} 10$ & 0.134 & 2.368 & 0.018 & Yes \\
\hline $\mathrm{EE} \rightarrow \mathrm{CI}$ & H11 & 0.183 & 3.539 & 0.000 & Yes \\
\hline $\mathrm{SEF} \rightarrow \mathrm{EE}$ & $\mathrm{H} 12$ & 0.389 & 6.354 & 0.000 & Yes \\
\hline $\mathrm{SEF} \rightarrow \mathrm{PE}$ & $\mathrm{H} 13$ & 0.265 & 5.541 & 0.000 & Yes \\
\hline $\mathrm{SEF} \rightarrow \mathrm{CAX}$ & H14 & -0.518 & 10.754 & 0.000 & Yes \\
\hline $\mathrm{CAX} \rightarrow \mathrm{EE}$ & H15 & -0.395 & 5.873 & 0.000 & Yes \\
\hline $\mathrm{ATT} \rightarrow \mathrm{CI}$ & H16 & 0.163 & 2.816 & 0.005 & Yes \\
\hline $\mathrm{FC} \rightarrow \mathrm{CI}$ & $\mathrm{H} 17$ & 0.210 & 3.541 & 0.000 & Yes \\
\hline $\mathrm{SN} \rightarrow \mathrm{CI}$ & H18 & 0.058 & 1.228 & 0.220 & No \\
\hline
\end{tabular}

In PLS, $R^{2}$ values represent "the amount of variance in the construct in question that is explained by the model" (Chin, 2010, p. 674). Figure 4 shows the correlation $R^{2}$ values for performance expectancy $\left(R^{2}=0.627\right)$, computer anxiety $\left(R^{2}=0.268\right)$, effort expectancy $\left(R^{2}=0.467\right)$, attitude $\left(R^{2}=0.426\right)$, satisfaction $\left(R^{2}=0.631\right)$ and continuous intention $\left(R^{2}=0.676\right)$ and the results of all path coefficients. The $R^{2}$ value of CI $(67.6 \%)$ clearly indicates that the proposed structural model could offer ample explanation on continuous intention to use Moodle. 


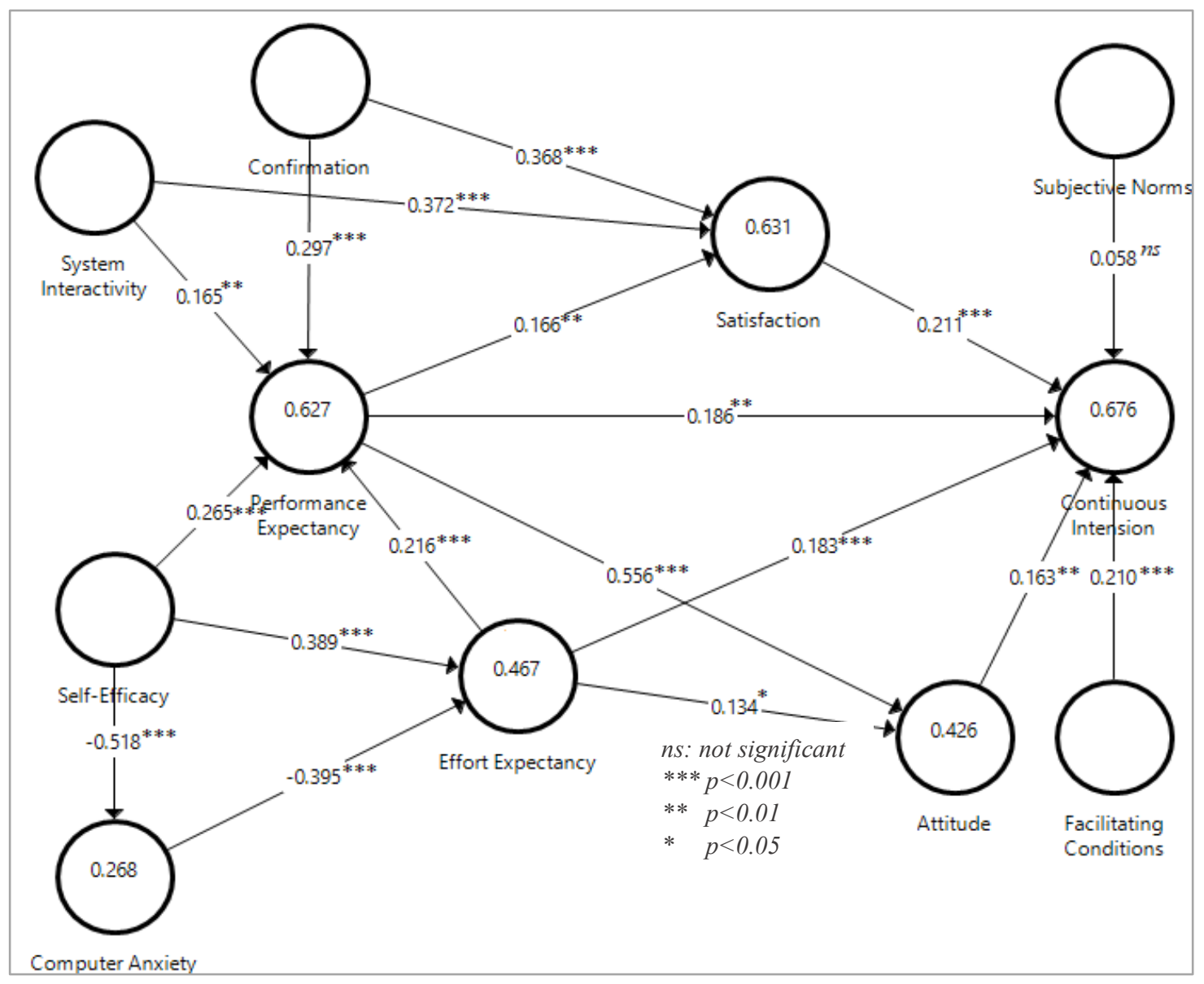

Figure 4. The structural model

Predictive relevance $\left(Q^{2}\right)$ values were also assessed by running a blindfolding procedure and calculated using the cross-validated redundancy approach. The findings show that the predictive relevance $\left(Q^{2}\right)$ for performance expectancy (0.463), computer anxiety (0.180), effort expectancy (0.368), attitude (0.390), satisfaction (0.467), and continuous intention (0.566), are bigger than zero as suggested by Chin (2010), Fornell and Cha (1994), and Hair, Sarstedt, Hopkins, et al. (2014). This indicates that the model has a significant predictive relevance.

As described by Hair, Sarstedt, Pieper et al. (2012), effect size $f^{2}$ "considers the relative impact of a particular exogenous latent variable on an endogenous latent variable by means of changes in the $R^{2}$ ". Similar to the effect size $f^{2}$, effect size $q^{2}$ shows an exogenous variable's contribution to an endogenous variable's $Q^{2}$ value (Hair, Sarstedt, Ringle, et al., 2012). Cohen (1988) suggested that $f^{2}$ effect sizes of $0.02,0.15$, and 0.35 are termed small, medium, and large, respectively. However, Aguinis et al. (2005), based on a 30 years review, have shown that the average effect size in tests of moderation is only 0.009. As such, Kenny (2018) argued that a more realistic standard for effect sizes might be $0.005,0.01$, and 0.025 for small, medium, and large, respectively. The author stated that these values are "optimistic" given the Aguinis et al. (2005) review. Table 7 shows the effect sizes results. While, for example, the effect size $f^{2}$ of effort expectancy on attitude is medium (0.017), according to Kenny (2018) standard effect size, its effect size $f^{2}$ on performance expectancy (0.058) and continuous intention (0.051) is large. Similarly, the effect size $q^{2}$ of effort expectancy on attitude (0.015) is considered medium, according to Kenny (2018) standard effect size, its effect size $q^{2}$ on performance expectancy (0.032) and continuous intention (0.076) is large. 
Table 7. Effect sizes

\begin{tabular}{|c|c|c|c|c|c|c|c|c|c|c|c|c|}
\hline & \multicolumn{6}{|c|}{$f^{2}$} & \multicolumn{6}{|c|}{$q^{2}$} \\
\hline & ATT & CAX & CI & EE & $\mathbf{P E}$ & SAT & ATT & CAX & $\mathrm{CI}$ & EE & PE & SAT \\
\hline$\overline{\text { ATT }}$ & & & 0.038 & & & & & & 0.023 & & & \\
\hline CAX & & & & 0.215 & & & & & & 0.142 & & \\
\hline CON & & & & & 0.110 & 0.169 & & & & & 0.052 & 0.084 \\
\hline EE & 0.017 & & 0.051 & & 0.058 & & 0.015 & & 0.076 & & 0.032 & \\
\hline FC & & & 0.055 & & & & & & 0.032 & & & \\
\hline PE & 0.302 & & 0.039 & & & 0.034 & 0.259 & & 0.018 & & & 0.017 \\
\hline SAT & & & 0.068 & & & & & & 0.035 & & & \\
\hline SEF & & 0.366 & & 0.207 & 0.102 & & & 0.220 & & 0.138 & 0.050 & \\
\hline SIN & & & & & 0.037 & 0.208 & & & & & 0.019 & 0.107 \\
\hline SN & & & 0.008 & & & & & & 0.002 & & & \\
\hline
\end{tabular}

The study extends the standard reporting of PLS-SEM by running the Importance-Performance Map Analysis (IPMA). The PLS-IPMA tests the total effect of an exogenous variable on a specific target endogenous variable (i.e., importance) with the averaged latent variable score of the exogenous construct (i.e., performance) (Hair, Hult et al., 2017). This test aims at detecting an exogenous variable that more effectively improved the value of the target endogenous variable (i.e., behavioral intention in this case) with its relatively high importance and low performance (Hock et al., 2010). As noted in Table 8, to predict students' continuous intention to use Moodle, performance expectancy has the highest importance (0.362), followed by effort expectancy (0.349), satisfaction (0.257), and self-efficacy (0.234). Yet, in terms of the performance of these constructs to predict students' continuous intention to use Moodle, system interactivity tops the list (85.300), followed by effort expectancy (84.390), satisfaction (84.932), and computer anxiety (80.911). These results imply that, though performance expectancy is the most important predictor of students' continuous intention to use Moodle, system interactivity should be the highest priority.

Table 8. PLS-IPMA analysis for behavioral intention to use Moodle

\begin{tabular}{|l|cc|}
\hline & Total Effect (Importance) & Index Value (Performance) \\
\hline Attitude & 0.139 & 72.177 \\
Computer Anxiety & -0.146 & 80.911 \\
Confirmation & 0.214 & 79.384 \\
Effort Expectancy & 0.349 & 84.390 \\
Facilitating Conditions & 0.191 & 75.816 \\
Performance Expectancy & 0.362 & 79.897 \\
Satisfaction & 0.257 & 84.932 \\
Self-efficacy & 0.234 & 73.641 \\
System Interactivity & 0.170 & 85.300 \\
Subjective Norms & 0.055 & 76.868 \\
\hline
\end{tabular}

Unlike covariance-based CB-SEM, such as AMOS and PLS, does not provide the overall modelgoodness-of-fit statistics. To address this issue, Hair, Hollingsworth et al. (2017) and Henseler et al. (2015) suggested using the Standardized Root Mean Square Residual (SRMR) fit index. For the structural model, the SRMR fit index is 0.051 , which is lower than the proposed threshold value of 0.08 (Hair, Hult et al., 2017; Henseler et al., 2015). 
Additionally, as suggested by Hair, Hult et al. (2017), the structural model was also assessed through the following measures: average path coefficient (APC), average R-squared (ARS), and average variance inflation factor (AVIF). Hair, Hult et al. (2017) recommended that the values for both the APC and ARS be significant at least at the 0.05 level, whereas the AVIF should be lower than 5 . Table 9 reveals that the model meets the recommended threshold values, suggesting that the data is a good fit with the proposed model.

Table 9. Inner model evaluation indices

\begin{tabular}{|llll|}
\hline $\begin{array}{l}\text { Average path } \\
\text { coefficient (APC) }\end{array}$ & $\begin{array}{l}\text { Average } \\
\text { R-squared (ARS) }\end{array}$ & $\begin{array}{l}\text { Average variance inflation } \\
\text { factor (AVIF) }\end{array}$ & SRMR fit index \\
\hline $0.270^{*}$ & $0.516^{*}$ & 3.55 & 0.051 \\
\hline Note: ${ }^{*} p<0.001$ & & &
\end{tabular}

\section{DISCUSSION AND IMPLICATIONS}

This study aimed at providing further understanding regarding the main factors that could shape students' intention to continue using LMSs, more specifically Moodle, in the Kuwaiti context. Therefore, to achieve this aim, the study adopted the ECM as a theory base, and extended it with other factors, such as EE, SEF, CAX, ATT, SN, and FC. Constructs' reliability and validity as well as model fit indices and predictive relevance were all achieved. As shown in Figure 4, the statistical results supported the predictive power of the conceptual model in explaining substantial variance in performance expectancy $\left(R^{2}=0.627\right)$, computer anxiety $\left(R^{2}=0.268\right)$, effort expectancy $\left(R^{2}=0.467\right)$, attitude $\left(R^{2}=0.426\right)$, satisfaction $\left(R^{2}=0.631\right)$, and continuous intention $\left(R^{2}=0.676\right)$. Such values of $R^{2}$ were within a highly acceptable level, which exceeded all the recommended values in this regard, such as $40 \%$ (Straub \& Gefen, 2004) and 30\% (Kline, 2016). This, in turn, provided further evidence supporting the conceptual model proposed in the current study to explain students' continuous intention to use Moodle. All study hypotheses, except H18 (Subjective Norms -> Continuous Intention), were established and confirmed with the results. Table 6 showed the hypotheses testing results.

As for the ECM constructs, the results indicated that confirmation has a significant positive relationship with performance expectancy and satisfaction. These significant relationships were supported in previous studies (e.g., Al-Emran et al., 2020; Alshurideh et al., 2020; S.-C. Chen et al., 2013; Hong et al., 2006; Joo et al., 2016, 2017; Oghuma et al., 2015, 2016). These results could be interpreted as when students' expectations toward Moodle benefits and advantages are confirmed, the system will, in turn, influence their performance and satisfaction. Further, the empirical results of this study have supported the significant relationship between performance expectancy and satisfaction with Moodle. This significant relationship was reported in prior studies (e.g., Al-Emran et al., 2020; Alshurideh et al., 2020; S.-C. Chen et al., 2013; Joo et al., 2017; Kim-Soon et al., 2017; Oghuma et al., 2016). This result could be attributed to the fact that when Moodle enhances the performance of the students, they would generally be satisfied with the system. The empirical results have also supported the significant relationships between performance expectancy and students' continuous intention and attitude towards Moodle. These results are in parallel with prior studies in the same context (e.g., AlEmran et al., 2020; S.-C. Chen et al., 2013; Y.-M. Cheng, 2014b; Dalvi-Esfahani et al., 2018; Joo et al., 2016; Sabah, 2016, 2019). These results imply that students seem to be more motivated to continue using Moodle and more likely to have a higher positive attitude towards the system if they perceive it as more effective, productive, and a useful technology in their learning. Finally, the statistical results also approved the significant impact of satisfaction on students' intention to continue using Moodle. The result is in line with prior studies (e.g., Al-Emran et al., 2020; Alshurideh et al., 2020; Joo et al., 2017; Sabah, 2019; Tam et al., 2018). This could be interpreted as students' satisfaction with Moodle will have a strong influence on their intention to continue using the system. 
The empirical results have approved the significant effects of system interactivity on performance expectancy and satisfaction. The results agree with existing literature in the LMS context (e.g., Baki et al., 2018; Chmiel et al., 2017; Cidral et al., 2018), and could be interpreted as, given the particular nature of Moodle's characteristics and features in enabling communication and interaction among the faculty, students, and peers, students will perceive the system useful and effective for their learning and this will exhibit their satisfaction with the system.

The results also confirmed that effort expectancy has a significant positive impact on performance expectancy and continuous intention. These results were observed in previous studies, in which there is a significant effect of effort expectancy on performance expectancy (e.g., Al-Emran et al., 2020; Alshurideh et al., 2020; Dalvi-Esfahani et al., 2018; Sabah, 2019). Prior studies also reported a significant relationship between effort expectancy and continuous intention in different technological contexts (e.g., Abdullah \& Ward, 2016; Alalwan et al., 2017, 2018; Al-Emran et al., 2020; Alshurideh et al., 2020; Joo et al., 2016; Rabaai et al., 2015; Rabaa'i, 2016; Sabah, 2016, 2019). These results could be based on the fact that when students perceived Moodle as effortless and easy to use, they will perceive the system as useful for their academic performance and this, in turn, will certainly improve their continuous intention to use the system. Along with its direct influence on performance expectancy and continuous intention, effort expectancy was approved to have an impact on students' attitude towards Moodle. This result was confirmed in previous studies (e.g., Abdullah \& Ward, 2016; Davis, 1989; Lust et al., 2012; Sabah, 2019; Wu \& Chen, 2017), and would be explained as students are more likely to have a higher positive attitude towards Moodle if they perceive it as requires less effort, not difficult and easy to use.

As expected, self-efficacy was empirically evidenced to be a crucial factor influencing effort expectancy and performance expectancy. These results were reported in previous studies (e.g., Al-Fraihat et al., 2020; Alshurideh et al., 2020; Ifinedo, 2017; Rana \& Dwivedi, 2015; Sabah, 2019; Salloum et al., 2019). This means students' confidence on their abilities and capabilities in using Moodle and accomplishing different learning tasks using this system will influence their perceptions towards the ease of use and usefulness of this system for their education. Additionally, the empirical results proved the negative impact of self-efficacy on computer anxiety. This result was also reported in prior studies (e.g., Sabah, 2019; Verkijika, 2020). This implies that students are not anxious about using Moodle because they have high self-confidence on their capabilities to use such a tool. This could be due to the fact that the majority of this study sample $(88 \%)$ have been using this system for more than a year.

The statistical results of this study demonstrated the significant path between attitude and continuous intention to use Moodle. Previous studies have confirmed this relationship (e.g., Al-Emran et al., 2020; Ifinedo, 2017, 2018; Sabah, 2019). This finding supports our argument, which was suggested by Dai et al. (2020), in which we assumed that attitude and satisfaction are two conceptually and theoretically different constructs as opposed to Bhattacharjee (2001a), who argued that the satisfaction construct plays the same role as the attitude. Dai et al. (2020) postulated that satisfaction pertains to the overall feeling about a past use experience, whereas attitude relates to feelings about future use. That is, satisfaction is an emotional response to a past use experience (Wixom \& Todd, 2005), while attitude is an affective reaction and an emotional response to a specific behavior and has an anticipatory effect on continuous intention (Dai et al., 2020). The results imply that students with a positive attitude towards Moodle will continue using the system for their education.

The empirical results confirmed the negative effect of computer anxiety on effort expectancy, which supported our proposed hypothesis. The same result was reported in prior studies (e.g., Brosnan, 1998; Sabah, 2019). This means that students are not too anxious about using Moodle and they perceived the system to be effortless and not difficult to use. This could be attributed to the fact that $45 \%$ of this study's respondents have been using Moodle for more than 3 years, and $43 \%$ have been using the system for 1-2 years. Moreover, the empirical results of this study confirmed a significant path between facilitating conditions and students' continuous intention to use Moodle. This means 
the more the facilitating conditions are associated with Moodle, such as resources availability, internet accessibility, compatibility with other smart devices such as mobile phones, and required knowledge and skills to use the LMS, the more students' continuous intention to use the system will be improved. The result is in parallel with previous studies' results (e.g., Al-Emran et al., 2020; Sabah, 2019). The result could be attributed to the fact that $45 \%$ of the study's respondents have been using Moodle for more than 3 years; therefore, they have adequate resources, knowledge, and capabilities to use the system.

Finally, as for the role of subjective norms, the results have been noticed in a different manner for what has been proposed in the conceptual model of this study and reported in previous empirical results on subjective norms (e.g., Al-Emran et al., 2020; Cheon et al., 2012; Dalvi-Esfahani et al., 2018; Huang, 2019; Raza et al., 2018; Sabah, 2019). In this study, subjective norms were not able to account for any statistical variance in continuous intention to use Moodle. This means that students in this study seem less interested in the recommendations of their reference groups, such as instructors, colleagues, and people who are important to them, in formulating their continuous intention to use Moodle. In his study concerning Chinese university students' acceptance of MOOCs, M. Zhou (2016) reported similar results of the non-significant role of subjective norms. This finding can be explained by two perspectives. First, the literature suggests that the impact of subjective norms will be significant in the initial phases of adoption and will gradually decrease over time as the system becomes more widely used (Al-Adwan et al., 2018; Uğur et al., 2016), and this could be confirmed by the fact that $45 \%$ of the study's respondents have been using Moodle for more than 3 years. Second, in line with M. Zhou's (2016, p. 206) argument, the subjective norms that influence continuous intentions may stem from multiple sources, including the influence of organization, instructors, peers, or other external influences. This decomposition of norms accords well with the differentiation between strong and weak social ties that is found in this environment. This argument is confirmed by Huang (2019) in his study of examining students continued use of desktop services. Huang (2019) has confirmed that users' intention to use or continue using a technology is subject to the interpersonal interaction on the basis of group norm, social identity, and subjective norm. The author found that, although subjective norm significantly influenced the subjects' continuance intention to use the desktop service, group norm and social identity had no significant and direct influence. Additionally, Cheung and Vogel's (2013) study on the use of Google Apps found that peer group emerged as a significant predictor of behavioral intention to use a Google App; however, the influences of instructors and of mass media were not significant.

\section{THEORETICAL IMPLICATIONS}

The theoretical implications of this study and its findings can be described in six points. First, our study has extended the ECM by integrating factors that are important to students' continuous intention to use Moodle (as an exemplar of LMSs), including system interactivity, effort expectancy, attitude, computer anxiety, self-efficacy, subjective norms, and facilitating conditions to study the continuous intention to use Moodle in the post-adoption phase. This is an important contribution to the LMS scientific community as most of the existing research concentrates either on LMS adoption or acceptance. Second, while this study confirmed the applicability and significance of the ECM constructs (confirmation, performance expectancy and satisfaction) in predicting a student's continuous intention to use Moodle, our study presents an extension to the original ECM by evaluating how these additional constructs, namely effort expectancy, attitude, self-efficacy, and facilitating conditions, significantly influence the continuous intention. The combined constructs in this study significantly increase the predictive power of this study's model and variance explained in the continuous use intention from $41 \%$, as reported by Bhattacharjee (2001a) in the original ECM study, to $67.6 \%$; therefore, providing a comprehensive view of the factors influencing students' continuous intention to use Moodle. Third, this study adds on the Kuwaiti literature context by focusing on the continuous intention to use Moodle in the post-adoption phase, which is, to the best of our knowledge, the first study that extended and empirically assessed the applicability of the ECM in the LMS context in a 
developing country - Kuwait. Fourth, with the high predictive relevance of $\left(Q^{2}=56.6 \%\right)$ and variance explained $\left(R^{2}=67.6 \%\right)$ in the continuous intention to use Moodle, the empirical results of this study provide evidence that the proposed model can be effective in explaining continuous use intention in general, and in the LMS context in specific. Fifth, this study goes beyond what was proposed by Bhattacharjee (2001a) in the original ECM by including a new construct (Attitude) alongside the ECM constructs, and proposing new causal paths (PE->AT'T and ATT- $>$ CI). This, in turn, demonstrates a significant contribution to the expansion of the ECM. Sixth, in line with Dai et al. (2020), this study conceptually and empirically differentiates between satisfaction and attitude, as two separate affect constructs, which were taken as interchangeable factors in ECM (Bhattacherjee, 2001a) and were disregarded by a large number of prior ECM studies concerned with continuous use intention.

\section{PRACTICAL IMPLICATIONS}

This study offers several useful practical implications. First, the findings of this study revealed important determinants that influence students' continuance intention to use Moodle after having experienced its use. When HEIs strategize how to increase continuance use rate of the LMS, they should factor in these determinants. Second, given the significant influence of system interactivity on performance expectancy and satisfaction, faculty members should modify their teaching approach by enabling communication and interaction among instructors, students, and peers using the LMS. By doing so, students will perceive the system useful and effective for their learning. This, in turn, will generate a higher positive attitude towards the usefulness of the LMS and exhibit students' satisfaction with the system. Third, given the significant influence of performance expectancy, satisfaction and attitude on continuous intention to use the LMS, HEIs should conduct training programs for students on the effective use of the LMS, this would increase students' awareness regarding the usefulness of the LMS, enhance their attitude towards the LMS and improve their satisfaction with the system. Additionally, the training programs on the effective use of the LMS will enhance students' self-efficacy and confidence in their abilities in using the LMS and accomplishing different learning tasks using this system. This will not only impact their perceptions towards the usefulness and ease of use of the system but will also reduce their computer anxiety in using the LMS. Fourth, given the significant role of effort expectancy in influencing performance expectancy, attitude and students' continuous intention to use Moodle, developers and system programmers should design the LMS with easy to use, high quality and customizable user interface. This will not only motivate students' performance expectancy but will also influence their attitude and continuous intention to use the system. Fifth, as for the facilitating conditions' role in influencing students' continuous intention, HEIs should ensure that technical support, adequate resources, and a "frequently asked questions and answers" section related to the LMS features, are available to students when using the LMS. Finally, developers and system programmers must ensure that the system is compatible with different operating systems, such as Android and iOS, for students who use their mobile devices or tablets to access the LMS.

\section{LIMITATIONS AND FUTURE RESEARCH}

Although our study provides valuable insights into the continuous intention to use Moodle, it has a number of limitations. First, this study is cross-sectional, and thus it does not demonstrate changes in students' continuous intention to use Moodle over time. Prior studies have found that subjects' expectations change over time (Liao et al., 2009). Also, external environmental factors can influence subjects' expectations (C.-L. Hsu et al., 2014). Therefore, a longitudinal empirical study should be conducted in future studies to explain how temporal changes affect students' continuous intention to use Moodle. Second, this study focused on Kuwaiti students using Moodle in one university in the State of Kuwait. Kuwait is a rich country with well-advanced technology infrastructure and its citizen are also more technology savvy (Rabaai et al., 2015; Statista, 2019a, 2019b) compared to citizens in many other developing countries. Future studies should investigate the proposed model in other countries with additional economic, environmental, and technological factors as well as different 
LMSs, such as BlackBoard. Third, this study focused on how different factors affected students' continuous intention to use Moodle but did not consider all determinants of a successful system, such as system quality, information quality, and instructional as well as course content quality. Thus, future research should devote attention to the effects of these quality characteristics of LMS. Fourth, the study sample is from an eastern culture and one country, which may limit the generalizability of the research findings. Therefore, future research should investigate a cross-cultural study, as cultural characteristics of users affect their decision process to continue using IS (C. Lee et al., 2017), where people from different cultures may have different norms for using various technologies (Sabah, 2019). Fifth, this study did not investigate students' personal characteristics, such as gender, age, and experience. However, Venkatesh et al. (2003) indicated that there is a significant relationship between users' personal characteristics and technology acceptance and usage. As such, future research should investigate the moderating effect of these variables on the continued use of Moodle. Finally, this study is based on self-reported questionnaire survey-based method. Future studies could use other tools for data collection, such as focus groups and interviews, or use a mixed-method approach (i.e., qualitative and quantitative) to provide a comprehensive understanding of students' continuous intention to use LMSs.

\section{CONCLUSION}

This study added on the existing scientific knowledge related to LMSs and examined different factors predicting Kuwaiti students' intention to continue using Moodle in the post-adoption phase, where studies on this phase of LMSs are scarce in general, and so far, have not been studied in the Kuwaiti context in particular. Our study has extended the ECM, i.e., the theoretical foundation, by integrating factors that are important to students' continuous intention, including system interactivity, effort expectancy, attitude, computer anxiety, self-efficacy, subjective norms, and facilitating conditions. To examine the proposed model, a quantitative survey was employed to collect data from students at a private American university in the State of Kuwait. The data was then analyzed using the PLS-SEM approach. This study confirmed how confirmation, performance expectancy, and satisfaction influenced students' continuous intention. The study investigated the influence of effort expectancy on performance expectancy and the influence of system interactivity on performance expectancy and satisfaction. The influence of performance expectancy and effort expectancy on attitude was examined. The relationships between self-efficacy, effort expectancy, performance expectancy, and computer anxiety were also studied. The main statistical results of this study supported the predictive validity and relevance of the proposed model by accounting for about $67.6 \%$ of variance and $56.6 \%$ of predictive relevance of the Kuwaiti students' continuous intention to use Moodle. While subjective norms were not statistically significant in predicting continuous intention, performance expectancy, effort expectancy, attitude, satisfaction, and facilitating conditions were all significant in predicting students' continuous intention to use Moodle. This study's results also confirmed that attitude and satisfaction are two conceptually and empirically different constructs, conflicting with Bhattacharjee (2001a) argument that satisfaction plays the same role as attitude.

\section{REFERENCES}

Abdous, M. (2019). Influence of satisfaction and preparedness on online students' feelings of anxiety. The Internet and Higher Education, 41, 34-44. https://doi.org/10.1016/j.iheduc.2019.01.001

Abdullah, F., \& Ward, R. (2016). Developing a general extended technology acceptance model for e-learning (GETAMEL) by analysing commonly used external factors. Computers in Human Behavior, 56, 238-256. https://doi.org/10.1016/i.chb.2015.11.036

Aguinis, H., Beaty, J. C., Boik, R. J., \& Pierce, C. A. (2005). Effect size and power in assessing moderating effects of categorical variables using multiple regression: A 30-year review. Journal of Applied Psychology, 90(1), 94-107. https://doi.org/10.1037/0021-9010.90.1.94 
Ajzen, I. (1991). The theory of planned behavior. Organizational Behavior and Human Decision Processes, 50(2), 179211. https://doi.org/10.1016/0749-5978(91)90020-T

Al-Adwan, A. S., Al-Madadha, A., \& Zvirzdinaite, Z. (2018). Modeling students' readiness to adopt mobile learning in higher education: An empirical study. International Review of Research in Open and Distributed Learning, 19(1). https://doi.org/10.19173/irrodl.v19i1.3256

Alalwan, A. A., Dwivedi, Y. K., \& Rana, N. P. (2017). Factors influencing adoption of mobile banking by Jordanian bank customers: Extending UTAUT2 with trust. International Journal of Information Management, 37(3), 99-110. https://doi.org/10.1016/j.ijinfomgt.2017.01.002

Alalwan, A. A., Dwivedi, Y. K., Rana, N. P., \& Algharabat, R. (2018). Examining factors influencing Jordanian customers' intentions and adoption of internet banking: Extending UTAUT2 with risk. Journal of Retailing and Consumer Services, 40, 125-138. https://doi.org/10.1016/i.jretconser.2017.08.026

Alalwan, A. A., Dwivedi, Y. K., Rana, N. P., \& Williams, M. D. (2016). Consumer adoption of mobile banking in Jordan: Examining the role of usefulness, ease of use, perceived risk and self-efficacy. Journal of Enterprise Information Management, 29(1), 118-139. https://doi.org/10.1108/JEIM-04-2015-0035

Aldiab, A., Chowdhury, H., Kootsookos, A., \& Alam, F. (2017). Prospect of eLearning in higher education sectors of Saudi Arabia: A review. Energy Procedia, 110, 574-580. https://doi.org/10.1016/j.egypro.2017.03.187

Al-Emran, M., Arpaci, I., \& Salloum, S. A. (2020). An empirical examination of continuous intention to use mlearning: An integrated model. Education and Information Technologies, 25(4), 2899-2918. https://doi.org/10.1007/s10639-019-10094-2

Alenezi, A. R., Abdul Karim, A. M., \& Veloo, A. (2010). An empirical investigation into the role of enjoyment, computer anxiety, computer self-efficacy and internet experience in influencing the students' intention to use e-learning: A case study from Saudi Arabian governmental universities. Turkish Online Journal of Educational Technology, 9(4), 22-34.

Al-Fraihat, D., Joy, M., Masa'deh, R., \& Sinclair, J. (2020). Evaluating e-learning systems success: An empirical study. Computers in Human Behavior, 102, 67-86. https://doi.org/10.1016/j.chb.2019.08.004

Ali, S., Uppal, M. A., \& Gulliver, S. R. (2018). A conceptual framework highlighting e-learning implementation barriers. Information Technology \& People, 31(1), 156-180. https://doi.org/10.1108/ITP-10-2016-0246

Alkhaldi, A. N., \& Kharma, Q. M. (2019). Customer's intention to adopt mobile banking services: The moderating influence of demographic factors. International Journal of Innovation and Technology Management, 16(05), 1-26. https://doi.org/10.1142/S0219877019500378

Almisad, B., \& Alsalim, M. (2020). Kuwaiti female university students' acceptance of the integration of smartphones in their learning: An investigation guided by a modified version of the unified theory of acceptance and use of technology (UTAUT). International Journal of Technology Enhanced Learning, 12(1), 1-19. https://doi.org/10.1504/IJTEL.2020.103812

Alraimi, K. M., Zo, H., \& Ciganek, A. P. (2015). Understanding the MOOCs continuance: The role of openness and reputation. Computers \& Education, 80, 28-38. https://doi.org/10.1016/j.compedu.2014.08.006

Alshurideh, M., Al Kurdi, B., \& Salloum, S. A. (2020). Examining the main mobile learning system drivers' effects: A mix empirical examination of both the Expectation-Confirmation Model (ECM) and the Technology Acceptance Model (TAM). In A. Hassanien, K. Shaalan, M. Tolba (Eds.), Proceedings of the 2019 International Conference on Advanced Intelligent Systems and Informatics (pp. 406-417). Springer. https://doi.org/10.1007/978-3-030-31129-2 37

Alwahaishi, S., \& Snásel, V. (2013). Acceptance and use of information and communications technology: A UTAUT and flow based theoretical model. Journal of Technology Management \& Innovation, 8(2), 61-73. https://doi.org/10.4067/S0718-27242013000200005

Arbaugh, J. B. (2002). Managing the on-line classroom: A study of technological and behavioral characteristics of web-based MBA courses. The Journal of High Technology Management Research, 13(2), 203-223. https://doi.org/10.1016/S1047-8310(02)00049-4 
Asnakew, Z. S. (2020). Customers' continuance intention to use mobile banking: Development and testing of an integrated model. The Review of Socionetwork Strategies, 14(1), 123-146. https://doi.org/10.1007/s12626$\underline{020-00060-7}$

Aypay, A., Celik, H. C., Aypay, A., \& Sever, M. (2012). Technology acceptance in education: A study of preservice teachers in Turkey. Turkish Online Journal of Educational Technology, 11(4), 264-272.

Bailey, A. A., Pentina, I., Mishra, A. S., \& Ben Mimoun, M. S. (2017). Mobile payments adoption by US consumers: An extended TAM. International Journal of Retail \& Distribution Management, 45(6), 626-640. https://doi.org/10.1108/IJRDM-08-2016-0144

Baki, R., Birgoren, B., \& Aktepe, A. (2018). A meta-analysis of factors affecting perceived usefulness and perceived ease of use in the adoption of e-learning systems. Turkish Online Journal of Distance Education, 19(4), 4-42. https://doi.org/10.17718/tojde.471649

Balakrishnan, V., \& Gan, C. L. (2016). Students' learning styles and their effects on the use of social media technology for learning. Telematics and Informatics, 33(3), 808-821. https://doi.org/10.1016/j.tele.2015.12.004

Bandura, A. (1977). Self-efficacy: Toward a unifying theory of behavioral change. Psycbological Review, 84(2), 191-215. https://doi.org/10.1037/0033-295X.84.2.191

Bandura, A. (1994). Self-efficacy. In V. S. Ramachaudran (Ed.), Encyclopedia of buman behavior (Vol. 4, pp. 71-81). Academic Press.

Beaudry, A., \& Pinsonneault, A. (2010). The other side of acceptance: Studying the direct and indirect effects of emotions on information technology use. MIS Quarterly, 34(4), 689-710. https://doi.org/10.2307/25750701

Bhattacherjee, A. (2001a). Understanding information systems continuance: An expectation-confirmation model. MIS Quarterly, 25(3), 351. https://doi.org/10.2307/3250921

Bhattacherjee, A. (2001b). An empirical analysis of the antecedents of electronic commerce service continuance. Decision Support Systems, 32(2), 201-214. https://doi.org/10.1016/S0167-9236(01)00111-7

Bhattacherjee, A., Perols, J., \& Sanford, C. (2008). Information technology continuance: A theoretic extension and empirical test. Journal of Computer Information Systems, 49(1), 17-26. https://doi.org/10.1080/08874417.2008.11645302

Bhattacherjee, A. \& Premkumar. (2004). Understanding changes in belief and attitude toward information technology usage: A theoretical model and longitudinal test. MIS Quarterly, 28(2), 229. https://doi.org/10.2307/25148634

Bhuasiri, W., Xaymoungkhoun, O., Zo, H., Rho, J. J., \& Ciganek, A. P. (2012). Critical success factors for elearning in developing countries: A comparative analysis between ICT experts and faculty. Computers \& Education, 58(2), 843-855. https://doi.org/10.1016/j.compedu.2011.10.010

Bloomfield, J., Roberts, J., \& While, A. (2010). The effect of computer-assisted learning versus conventional teaching methods on the acquisition and retention of handwashing theory and skills in pre-qualification nursing students: A randomised controlled trial. International Journal of Nursing Studies, 47, 287-294. https://doi.org/10.1016/j.ijnurstu.2009.08.003

Boonsiritomachai, W., \& Pitchayadejanant, K. (2017). Determinants affecting mobile banking adoption by generation Y based on the Unified Theory of Acceptance and Use of Technology Model modified by the Technology Acceptance Model concept. Kasetsart Journal of Social Sciences, 40(2), 349-358. https://doi.org/10.1016/j.kjss.2017.10.005

Brosnan, M. J. (1998). The impact of computer anxiety and self-efficacy upon performance. Journal of Computer Assisted Learning, 14(3), 223-234. https://doi.org/10.1046/j.1365-2729.1998.143059.x

Brown, K. G., \& Charlier, S. D. (2013). An integrative model of e-learning use: Leveraging theory to understand and increase usage. Human Resource Management Review, 23(1), 37-49. https://doi.org/10.1016/j.hrmr.2012.06.004 
Chen, H.-R., \& Tseng, H.-F. (2012). Factors that influence acceptance of web-based e-learning systems for the in-service education of junior high school teachers in Taiwan. Evaluation and Program Planning, 35(3), 398406. https://doi.org/10.1016/j.evalprogplan.2011.11.007

Chen, S.-C., Liu, M.-L., \& Lin, C.-P. (2013). Integrating technology readiness into the expectation-confirmation model: An empirical study of mobile services. Cyberpsychology, Behavior, and Social Networking, 16(8), 604-612. https://doi.org/10.1089/cyber.2012.0606

Cheng, M., \& Yuen, A. H. K. (2018). Student continuance of learning management system use: A longitudinal exploration. Computers \& Education, 120, 241-253. https://doi.org/10.1016/j.compedu.2018.02.004

Cheng, M., \& Yuen, A. H. K. (2019). Cultural divides in acceptance and continuance of learning management system use: A longitudinal study of teenagers. Educational Technology Research and Development, 67(6), 16131637. https://doi.org/10.1007/s11423-019-09680-5

Cheng, P., OuYang, Z., \& Liu, Y. (2019). Understanding bike sharing use over time by employing extended technology continuance theory. Transportation Research Part A: Policy and Practice, 124, 433-443. https://doi.org/10.1016/j.tra.2019.04.013

Cheng, Y., Sharma, S., Sharma, P., \& Kulathunga, K. (2020). Role of personalization in continuous use intention of mobile news apps in India: Extending the UTAUT2 model. Information, 11(1), 33. https://doi.org/10.3390/info11010033

Cheng, Y.-M. (2012). Effects of quality antecedents on e-learning acceptance. Internet Research, 22(3), 361-390. https://doi.org/10.1108/10662241211235699

Cheng, Y.-M. (2014a). Extending the expectation-confirmation model with quality and flow to explore nurses' continued blended e-learning intention. Information Technology \& People, 27(3), 230-258. https://doi.org/10.1108/ITP-01-2013-0024

Cheng, Y.-M. (2014b). Why do users intend to continue using the digital library? An integrated perspective. Aslib Journal of Information Management, 66(6), 640-662. https://doi.org/10.1108/AJIM-05-2013-0042

Cheon, J., Lee, S., Crooks, S. M., \& Song, J. (2012). An investigation of mobile learning readiness in higher education based on the theory of planned behavior. Computers \& Education, 59(3), 1054-1064. https://doi.org/10.1016/j.compedu.2012.04.015

Cheung, R., \& Vogel, D. (2013). Predicting user acceptance of collaborative technologies: An extension of the technology acceptance model for e-learning. Computers \& Education, 63, 160-175. https://doi.org/10.1016/j.compedu.2012.12.003

Chin, W. W. (2010). Bootstrap cross-validation indices for PLS path model assessment. In V. Esposito Vinzi, W. Chin, J. Henseler, \& H. Wang (Eds.), Handbook of partial least squares. Springer. https://doi.org/10.1007/978-3-540-32827-8_ 4

Chmiel, A. S., Shaha, M., \& Schneider, D. K. (2017). Introduction of blended learning in a master program: Developing an integrative mixed method evaluation framework. Nurse Education Today, 48, 172-179. https://doi.org/10.1016/j.nedt.2016.10.008

Choi, K., Wang, Y., \& Sparks, B. (2019). Travel app users' continued use intentions: It's a matter of value and trust. Journal of Travel \& Tourism Marketing, 36(1), 131-143. https://doi.org/10.1080/10548408.2018.1505580

Cidral, W. A., Oliveira, T., Di Felice, M., \& Aparicio, M. (2018). E-learning success determinants: Brazilian empirical study. Computers \& Education, 122, 273-290. https://doi.org/10.1016/j.compedu.2017.12.001

Cohen, J. (1988). Statistical power analysis for the behavioral sciences. Lawrence Erlbaum.

Compeau, D., \& Higgins, C. (1995). Application of social cognitive theory to training for computer skills. Information Systems Research, 6(2), 118-143. https://doi.org/10.1287/isre.6.2.118

Conijn, R., Snijders, C., Kleingeld, A., \& Matzat, U. (2017). Predicting student performance from LMS data: A comparison of 17 blended courses using Moodle LMS. IEEE Transactions on Learning Technologies, 10(1), 17 29. https://doi.org/10.1109/TLT.2016.2616312 
Dai, H. M., Teo, T., Rappa, N. A., \& Huang, F. (2020). Explaining Chinese university students' continuance learning intention in the MOOC setting: A modified expectation confirmation model perspective. Computers \& Education, 150, 103850. https://doi.org/10.1016/j.compedu.2020.103850

Dalvi-Esfahani, M., Wai Leong, L., Ibrahim, O., \& Nilashi, M. (2018). Explaining students' continuance intention to use mobile web 2.0 learning and their perceived learning: An integrated approach. Journal of Educational Computing Research, 57(8), 1956-2005. https://doi.org/10.1177/0735633118805211

Daniela, L., Strods, R., \& Kalnina, D. (2019). Technology-Enhanced Learning (TEL) in higher education: Where are we now? In M. Lytras, L. Daniela, \& A. Visvizi (Eds.), Knowledge-intensive economies and opportunities for social, organizational, and technological growth (pp. 12-24). IGI Global. https://doi.org/10.4018/978-1-52257347-0.ch002

Davis, F. D. (1989). Perceived usefulness, perceived ease of use, and user acceptance of information technology. MIS Quarterly, 13(3), 319-340. https://doi.org/10.2307/249008

Ding, Y. (2019). Looking forward: The role of hope in information system continuance. Computers in Human Behavior, 91, 127-137. https://doi.org/10.1016/j.chb.2018.09.002

Dönmez-Turan, A., \& Kır, M. (2019). User anxiety as an external variable of technology acceptance model: A meta-analytic study. Procedia Computer Science, 158, 715-724. https://doi.org/10.1016/j.procs.2019.09.107

Echeverria, L., Cobos, R., \& Morales, M. (2013). Designing and evaluating collaborative learning scenarios in Moodle LMS courses. In Y. Luo (Ed.) Cooperative design, visualization, and engineering (pp. 61-66). Springer. https://doi.org/10.1007/978-3-642-40840-3 10

El Mawas, N., Oubahssi, L., \& Laforcade, P. (2016). A method for making explicit LMS instructional design languages. Technology, Instruction, Cognition \& Learning, 10(3), 203-226.

Eom, S. B., \& Ashill, N. J. (2018). A system's view of e-learning success model. Decision Sciences Journal of Innovative Education, 16(1), 42-76. https://doi.org/10.1111/dsji.12144

Faham, E., \& Asghari, H. (2019). Determinants of behavioral intention to use e-textbooks: A study in Iran's agricultural sector. Computers and Electronics in Agriculture, 165, 104935. https://doi.org/10.1016/i.compag.2019.104935

Fearnley, M. R., \& Amora, J. T. (2020). Learning management system adoption in higher education using the extended technology acceptance model. LAFOR Journal of Education, 8(2), 89-106. https://doi.org/10.22492/ije.8.2.05

Fornell, C., \& Cha, J. (1994). Partial least squares. In R. Bagozzi (Ed.), Advanced methods of marketing research (pp. 52-78). Blackwell.

Fornell, C., \& Larcker, D. F. (1981). Structural equation models with unobservable variables and measurement error: Algebra and statistics. Journal of Marketing Research, 18(3), 382-388. https://doi.org/10.1177/002224378101800313

Foroughi, B., Iranmanesh, M., \& Hyun, S. S. (2019). Understanding the determinants of mobile banking continuance usage intention. Journal of Enterprise Information Management, 32(6), 1015-1033. https://doi.org/10.1108/JEIM-10-2018-0237

Fu, X., Zhang, J., \& Chan, F. T. S. (2018). Determinants of loyalty to public transit: A model integrating Satisfaction-Loyalty Theory and Expectation-Confirmation Theory. Transportation Researcb Part A: Policy and Practice, 113, 476-490. https://doi.org/10.1016/j.tra.2018.05.012

Gasaymeh, A. M. M., \& Waswas, D. M. (2019). The use of TAM to investigate university students' acceptance of the formal use of smartphones for learning: A qualitative approach. International Journal of Technology Enbanced Learning, 11(2), 136. https://doi.org/10.1504/IJTEL.2019.098756

Gilani, M. S., Iranmanesh, M., Nikbin, D., \& Zailani, S. (2017). EMR continuance usage intention of healthcare professionals. Informatics for Health and Social Care, 42(2), 153-165. https://doi.org/10.3109/17538157.2016.1160245

Green, K. R., \& Chewning, H. L. (2020). The fault in our systems: LMS as a vehicle for critical pedagogy. TecbTrends, 64, 423-431. https://doi.org/10.1007/s11528-020-00480-w 
Gunasinghe, A., Hamid, J. A., Khatibi, A., \& Azam, S. M. F. (2019a). The adequacy of UTAUT-3 in interpreting academician's adoption to e-Learning in higher education environments. Interactive Technology and Smart Education, 17(1), 86-106. https://doi.org/10.1108/ITSE-05-2019-0020

Gunasinghe, A., Hamid, J. A., Khatibi, A., \& Azam, S. M. F. (2019b). Does anxiety impede VLE adoption intentions of state university lecturers? A study based on modified UTAUT framework. European Journal of Social Sciences Studies, 4(4), 46-70. https://doi.org/10.5281/zenodo.3358121

Guo, X., Sun, Y., Wang, N., Peng, Z., \& Yan, Z. (2013). The dark side of elderly acceptance of preventive mobile health services in China. Electronic Markets, 23(1), 49-61. https://doi.org/10.1007/s12525-012-0112-4

Gupta, A., Yousaf, A., \& Mishra, A. (2020). How pre-adoption expectancies shape post-adoption continuance intentions: An extended expectation-confirmation model. International Journal of Information Management, 52, 102094. https://doi.org/10.1016/j.ijinfomgt.2020.102094

Hair, J. F., Hollingsworth, C., Randolph, A., \& Chong, A. (2017). An updated and expanded assessment of PLS-SEM in information systems research. Industrial Management \& Data Systems, 117(3), 442-458. https://doi.org/10.1108/IMDS-04-2016-0130

Hair, J. F., Hult, T., Ringle, C., \& Sarstedt, M. (2017). A primer on Partial Least Squares Structural Equation Modeling (PLS-SEM). SAGE Publications.

Hair, J. F., Sarstedt, M., Hopkins, L., \& G. Kuppelwieser, V. (2014). Partial least squares structural equation modeling (PLS-SEM): An emerging tool in business research. European Business Review, 26(2), 106-121. https://doi.org/10.1108/EBR-10-2013-0128

Hair, J. F., Sarstedt, M., Pieper, T. M., \& Ringle, C. M. (2012). The use of partial least squares structural equation modeling in strategic management research: A review of past practices and recommendations for future applications. Long Range Planning, 45(5), 320-340. https://doi.org/10.1016/j.lrp.2012.09.008

Hair, J. F., Sarstedt, M., Ringle, C. M., \& Mena, J. A. (2012). An assessment of the use of partial least squares structural equation modeling in marketing research. Journal of the Academy of Marketing Science, 40(3), 414 433. https://doi.org/10.1007/s11747-011-0261-6

He, J., \& Freeman, L. (2010). Understanding the formation of general computer self-efficacy. Communications of the Association for Information Systems, 26(1). https://doi.org/10.17705/1CAIS.02612

Henseler, J., Ringle, C. M., \& Sarstedt, M. (2015). A new criterion for assessing discriminant validity in variancebased structural equation modeling. Journal of the Academy of Marketing Science, 43(1), 115-135. https://doi.org/10.1007/s11747-014-0403-8

Henseler, J., Ringle, C. M., \& Sinkovics, R. R. (2009). The use of partial least squares path modeling in international marketing. New Challenges to International Marketing, 20, 277-319. https://doi.org/10.1108/S14747979(2009)0000020014

Hock, C., Ringle, C. M., \& Sarstedt, M. (2010). Management of multi-purpose stadiums: Importance and performance measurement of service interfaces. International Journal of Services Technology and Management, 14(2/3), 188-207. https://doi.org/10.1504/IJSTM.2010.034327

Hone, K. S., \& El Said, G. R. (2016). Exploring the factors affecting MOOC retention: A survey study. Computers \& Education, 98, 157-168. https:// doi.org/10.1016/j.compedu.2016.03.016

Hong, S., Thong, J. Y. L., \& Tam, K. Y. (2006). Understanding continued information technology usage behavior: A comparison of three models in the context of mobile internet. Decision Support Systems, 42(3), 18191834. https://doi.org/10.1016/j.dss.2006.03.009

Hsiao, W.-H., \& Chang, T.-S. (2014). Understanding consumers' continuance intention towards mobile advertising: A theoretical framework and empirical study. Behaviour \& Information Technology, 33(7), 730-742. https://doi.org/10.1080/0144929X.2013.789081

Hsu, C.-L., Yu, C.-C., \& Wu, C.-C. (2014). Exploring the continuance intention of social networking websites: An empirical research. Information Systems and E-Business Management, 12(2), 139-163. https://doi.org/10.1007/s10257-013-0214-3 
Hsu, M. K., Wang, S. W., \& Chiu, K. K. (2009). Computer attitude, statistics anxiety and self-efficacy on statistical software adoption behavior: An empirical study of online MBA learners. Computers in Human Behavior, 25(2), 412-420. https://doi.org/10.1016/j.chb.2008.10.003

Hsu, M.-H., \& Chiu, C.-M. (2004). Internet self-efficacy and electronic service acceptance. Decision Support Systems, 38(3), 369-381. https://doi.org/10.1016/j.dss.2003.08.001

Huang, L., Zhang, J., \& Liu, Y. (2017). Antecedents of student MOOC revisit intention: Moderation effect of course difficulty. International Journal of Information Management, 37(2), 84-91. https://doi.org/10.1016/j.ijinfomgt.2016.12.002

Huang, Y.-M. (2016). The factors that predispose students to continuously use cloud services: Social and technological perspectives. Computers \& Education, 97, 86-96. https://doi.org/10.1016/j.compedu.2016.02.016

Huang, Y.-M. (2019). Examining students' continued use of desktop services: Perspectives from expectationconfirmation and social influence. Computers in Human Behavior, 96, 23-31. https://doi.org/10.1016/j.chb.2019.02.010

Ifinedo, P. (2017). Examining students' intention to continue using blogs for learning: Perspectives from technology acceptance, motivational, and social-cognitive frameworks. Computers in Human Behavior, 72, 189199. https://doi.org/10.1016/i.chb.2016.12.049

Ifinedo, P. (2018). Determinants of students' continuance intention to use blogs to learn: An empirical investigation. Behaviour \& Information Technology, 37(4), 381-392. https://doi.org/10.1080/0144929X.2018.1436594

Ifinedo, P., Pyke, J., \& Anwar, A. (2018). Business undergraduates' perceived use outcomes of Moodle in a blended learning environment: The roles of usability factors and external support. Telematics and Informatics, 35(1), 93-102. https://doi.org/10.1016/j.tele.2017.10.001

Iqbal, S., \& Qureshi, I. A. (2012). M-learning adoption: A perspective from a developing country. The International Review of Research in Open and Distributed Learning, 13(3), 147-164. https://doi.org/10.19173/irrodl.v13i3.1152

Jaradat, M.-I. R., \& Al Rababaa, M. S. (2013). Assessing key factor that influence on the acceptance of mobile commerce based on modified UTAUT. International Journal of Business and Management, 8(23), 102-112. https://doi.org/10.5539/ijbm.v8n23p102

Jashapara, A., \& Tai, W.-C. (2011). Knowledge mobilization through e-learning systems: Understanding the mediating roles of self-efficacy and anxiety on perceptions of ease of use. Information Systems Management, 28(1), 71-83. https://doi.org/10.1080/10580530.2011.536115

Joo, Y. J., Kim, N., \& Kim, N. H. (2016). Factors predicting online university students' use of a mobile learning management system (m-LMS). Educational Technology Research and Development, 64(4), 611-630. https://doi.org/10.1007/s11423-016-9436-7

Joo, Y. J., Park, S., \& Shin, E. K. (2017). Students' expectation, satisfaction, and continuance intention to use digital textbooks. Computers in Human Behavior, 69, 83-90. https://doi.org/10.1016/j.chb.2016.12.025

Joo, Y. J., So, H.-J., \& Kim, N. H. (2018). Examination of relationships among students' self-determination, technology acceptance, satisfaction, and continuance intention to use K-MOOCs. Computers \& Education, 122, 260-272. https://doi.org/10.1016/j.compedu.2018.01.003

Kenny, D. (2018). Moderator variables: Introduction. http://davidakenny.net/cm/moderation.htm

Khadka, B. K., Rokaya, B. B., Roka, J., \& Bhatta, P. D. (2020). Perceptions, issues, and challenges towards online and alternative examinations system: A case of mid-western university. International Journal of Innovative Science and Research Technology, 5(11), 105-114.

Kim, B. (2010). An empirical investigation of mobile data service continuance: Incorporating the theory of planned behavior into the expectation-confirmation model. Expert Systems with Applications, 37(10), 70337039. https://doi.org/10.1016/j.eswa.2010.03.015 
Kim, B., \& Park, M. J. (2018). Effect of personal factors to use ICTs on e-learning adoption: Comparison between learner and instructor in developing countries. Information Technology for Development, 24(4), 706-732. https://doi.org/10.1080/02681102.2017.1312244

Kim-Soon, N., Ibrahim, M. A., Razzaly, W., Ahmad, A. R., \& Sirisa, N. M. X. (2017). Mobile technology for learning satisfaction among students at Malaysian Technical Universities (MTUN). Advanced Science Letters, 23(1), 223-226. https://doi.org/10.1166/asl.2017.7140

Kline, R. B. (2016). Principles and practice of structural equation modeling (4th ed.). Guilford Publications.

Kuhnel, M., Seiler, L., Honal, A., \& Ifenthaler, D. (2018). Mobile learning analytics in higher education: Usability testing and evaluation of an app prototype. Interactive Technology and Smart Education, 15(4), 332-347. https://doi.org/10.1108/ITSE-04-2018-0024

Kumar, A., Adlakaha, A., \& Mukherjee, K. (2018). The effect of perceived security and grievance redressal on continuance intention to use M-wallets in a developing country. International Journal of Bank Marketing, 36(7), 1170-1189. https://doi.org/10.1108/IJBM-04-2017-0077

Lee, B.-C., Yoon, J.-O., \& Lee, I. (2009). Learners' acceptance of e-learning in South Korea: Theories and results. Computers \& Education, 53(4), 1320-1329. https://doi.org/10.1016/j.compedu.2009.06.014

Lee, C., Yeung, A. S., \& Ip, T. (2017). University English language learners' readiness to use computer technology for self-directed learning. System, 67, 99-110. https://doi.org/10.1016/i.system.2017.05.001

Liao, C., Palvia, P., \& Chen, J.-L. (2009). Information technology adoption behavior life cycle: Toward a Technology Continuance Theory (TCT). International Journal of Information Management, 29(4), 309-320. https://doi.org/10.1016/i.ijinfomgt.2009.03.004

Liébana-Cabanillas, F., Marinkovic, V., Ramos De Luna, I., \& Kalinic, Z. (2018). Predicting the determinants of mobile payment acceptance: A hybrid SEM-neural network approach. Technological Forecasting and Social Change, 129, 117-130. https://doi.org/10.1016/i.techfore.2017.12.015

Lim, S. H., Kim, D. J., Hur, Y., \& Park, K. (2019). An empirical study of the impacts of perceived security and knowledge on continuous intention to use mobile FinTech payment services. International Journal of Human-Computer Interaction, 35(10), 886-898. https://doi.org/10.1080/10447318.2018.1507132

Lust, G., Elen, J., \& Clarebout, G. (2012). Adopting webcasts over time: The influence of perceptions and attitudes. Journal of Computing in Higher Education, 24(1), 40-57. https://doi.org/10.1007/s12528-011-9052-9

Lwoga, E. (2014). Critical success factors for adoption of web-based learning management systems in Tanzania. International Journal of Education and Development Using Information and Communication Technology, 10(1), 4 21.

Merikivi, J., Tuunainen, V., \& Nguyen, D. (2017). What makes continued mobile gaming enjoyable? Computers in Human Behavior, 68, 411-421. https://doi.org/10.1016/i.chb.2016.11.070

Moodle. (2020). Moodle statistics. https://stats.moodle.org

Moreno, V., Cavazotte, F., \& Alves, I. (2017). Explaining university students' effective use of e-learning platforms: Effective use of e-learning platforms. British Journal of Educational Technology, 48(4), 995-1009. https://doi.org/10.1111/bjet.12469

Mpungose, C. B. (2020). Is Moodle or WhatsApp the preferred e-learning platform at a South African university? First-year students' experiences. Education and Information Technologies, 25(2), 927-941. https://doi.org/10.1007/s10639-019-10005-5

Mubin, O., Novoa, M., \& Al Mahmud, A. (2017). Infusing technology driven design thinking in industrial design education: A case study. Interactive Technology and Smart Education, 14(3), 216-229. https://doi.org/10.1108/ITSE-01-2017-0008

Nascimento, B., Oliveira, T., \& Tam, C. (2018). Wearable technology: What explains continuance intention in smartwatches? Journal of Retailing and Consumer Services, 43, 157-169. https://doi.org/10.1016/i.jretconser.2018.03.017 
Nov, O., \& Ye, C. (2009). Resistance to change and the adoption of digital libraries: An integrative model. Journal of the American Society for Information Science and Technology, 60(8), 1702-1708. https://doi.org/10.1002/asi.21068

Nunnally, C., \& Bernstein, H. (1994). Psychometric theory (3rd ed.). McGrawHill.

Nysveen, H., \& Pedersen, P. E. (2016). Consumer adoption of RFID-enabled services. Applying an extended UTAUT model. Information Systems Frontiers, 18(2), 293-314. https://doi.org/10.1007/s10796-014-9531-4

Oertzen, A.-S., \& Odekerken-Schröder, G. (2019). Achieving continued usage in online banking: A post-adoption study. International Journal of Bank Marketing, 37(6), 1394-1418. https://doi.org/10.1108/IJBM-092018-0239

Oghuma, A. P., Chang, Y., Libaque-Saenz, C. F., Park, M.-C., \& Rho, J. J. (2015). Benefit-confirmation model for post-adoption behavior of mobile instant messaging applications: A comparative analysis of KakaoTalk and Joyn in Korea. Telecommunications Policy, 39(8), 658-677. https://doi.org/10.1016/j.telpol.2015.07.009

Oghuma, A. P., Libaque-Saenz, C. F., Wong, S. F., \& Chang, Y. (2016). An expectation-confirmation model of continuance intention to use mobile instant messaging. Telematics and Informatics, 33(1), 34-47. https://doi.org/10.1016/j.tele.2015.05.006

Oh, E. G., Huang, W.-H. D., Hedayati Mehdiabadi, A., \& Ju, B. (2018). Facilitating critical thinking in asynchronous online discussion: Comparison between peer- and instructor-redirection. Journal of Computing in Higher Education, 30(3), 489-509. https://doi.org/10.1007/s12528-018-9180-6

Oliver, R. (1997). Satisfaction: A behavioral perspective on the consumer. McGrawHill.

Oliver, R. (1980). A cognitive model of the antecedents and consequences of satisfaction decisions. Journal of Marketing Research, 17(4), 460-469. https://doi.org/10.1177/002224378001700405

Park, J., Ahn, J., Thavisay, T., \& Ren, T. (2019). Examining the role of anxiety and social influence in multi-benefits of mobile payment service. Journal of Retailing and Consumer Services, 47, 140-149. https://doi.org/10.1016/i.jretconser.2018.11.015

Partala, T., \& Saari, T. (2015). Understanding the most influential user experiences in successful and unsuccessful technology adoptions. Computers in Human Behavior, 53, 381-395. https://doi.org/10.1016/i.chb.2015.07.012

Pérez-Pérez, M., Serrano-Bedia, A. M., \& García-Piqueres, G. (2019). An analysis of factors affecting students' perceptions of learning outcomes with Moodle. Journal of Further and Higher Education, 44(8), 1114-1129. https://doi.org/10.1080/0309877X.2019.1664730

Pituch, K. A., \& Lee, Y. (2006). The influence of system characteristics on e-learning use. Computers \& Education, 47(2), 222-244. https://doi.org/10.1016/i.compedu.2004.10.007

Premkumar, G., \& Bhattacherjee, A. (2008). Explaining information technology usage: A test of competing models. Omega, 36(1), 64-75. https://doi.org/10.1016/j.omega.2005.12.002

Qudsyi, H., \& Putri, M. I. (2016). Self-efficacy and anxiety of national examination among high school students. Procedia - Social and Behavioral Sciences, 217, 268-275. https://doi.org/10.1016/i.sbspro.2016.02.082

Rabaa'i, A. A. (2012). Evaluating the success of large-scale, integrated information systems through the lens of IS-impact and IS-support [Unpublished doctoral dissertation, Queensland University of Technology, Australia].

Rabaai, A. A. (2015). An empirical investigation on the adoption of e-government in developing countries: The case of Jordan. Computer and Information Science, 8(3), 83-102. https://doi.org/10.5539/cis.v8n3p83

Rabaa'i, A. A. (2016). Extending the technology acceptance model (TAM) to assess students' behavioural intentions to adopt an e-learning system: The case of Moodle as a learning tool. Journal of Emerging Trends in Engineering and Applied Sciences, 7(1), 13-30.

Rabaa’i, A. A. (2017a). Holistic procedures for contemporary formative construct validation using PLS: A comprehensive example. International Journal of Business Information Systems, 25(3), 279-318.

https://doi.org/10.1504/IJBIS.2017.084436 
Rabaa'i, A. A. (2017b). The use of UTAUT to investigate the adoption of e-government in Jordan: A cultural perspective. International Journal of Business Information Systems, 24(3), 285-315. https://doi.org/10.1504/IJBIS.2017.082037

Rabaa'i, A. A. (in press). An investigation into the acceptance of mobile wallets in the FinTech era: An empirical study from Kuwait. International Journal of Business Information Systems.

Rabaa'i, A. A., \& AlMaati, S. (2021). Exploring the determinants of users' continuance intention to use mobile banking services in Kuwait: Extending the expectation-confirmation model. Asia Pacific Journal of Information Systems, 31(2), 141-184. https://doi.org/10.14329/apjis.2021.31.2.141

Rabaa'i, A. A., Bhat, H., \& Abu Al Maati, S. (2018). Theorising social networks addiction: An empirical investigation. International Journal of Social Media and Interactive Learning Environments, 6(1), 1-24. https://doi.org/10.1504/IJSMILE.2018.10013518

Rabaa'i, A. A., Tate, M., \& Gable, G. (2015). Can't see the trees for the forest? Why IS-ServQual items matter. Asia Pacific Journal of Information Systems, 25(2), 211-238. https://doi.org/10.14329/apjis.2015.25.2.211

Rabaa'i, A. A., \& Zhu, X. (2021). Understanding the determinants of wearable payment adoption: An empirical study. Interdisciplinary Journal of Information, Knowledge, and Management, 16, 173-211. https://doi.org/10.28945/4746

Rabaa'i, A. A., Zogheib, B., AlShatti, A., \& AlJamal, E. M. (2015). Adoption of e-government in developing countries: The case of the state of Kuwait. Journal of Global Research in Computer Science, 6(10), 6-21.

Rahi, S., Abd. Ghani, M., Alnaser, F. M., \& Ngah, A. H. (2018). Investigating the role of unified theory of acceptance and use of technology (UTAUT) in internet banking adoption context. Management Science Letters, 8, 173-186. https://doi.org/10.5267/j.msl.2018.1.001

Rana, N. P., \& Dwivedi, Y. K. (2015). Citizen's adoption of an e-government system: Validating extended social cognitive theory (SCT). Government Information Quarterly, 32(2), 172-181. https://doi.org/10.1016/j.giq.2015.02.002

Raza, S. A., Umer, A., Qazi, W., \& Makhdoom, M. (2018). The effects of attitudinal, normative, and control beliefs on m-learning adoption among the students of higher education in Pakistan. Journal of Educational Computing Research, 56(4), 563-588. https://doi.org/10.1177/0735633117715941

Rhode, J., Richter, S., Gowen, P., Miller, T., \& Wills, C. (2017). Understanding faculty use of the learning management system. Online Learning, 21(3), 68-86. https://doi.org/10.24059/olj.v21i3.1217

Ringle, C., Wende, S., \& Becker, J. (2015). SmartPLS 3. Boenningstedt: SmartPLS GmbH. http://www.smartpls.com

Rodger, J. A., \& Gonzalez, S. P. (2014). A study on emotion and memory in technology adoption. Journal of Computer Information Systems, 54(4), 31-41. https://doi.org/10.1080/08874417.2014.11645720

Sabah, N. M. (2016). Exploring students' awareness and perceptions: Influencing factors and individual differences driving m-learning adoption. Computers in Human Behavior, 65, 522-533. https://doi.org/10.1016/j.chb.2016.09.009

Sabah, N. M. (2019). Motivation factors and barriers to the continuous use of blended learning approach using Moodle: Students' perceptions and individual differences. Behaviour \& Information Technology, 39(8), 875-898. https://doi.org/10.1080/0144929X.2019.1623323

Salloum, S. A., Qasim Mohammad Alhamad, A., Al-Emran, M., Abdel Monem, A., \& Shaalan, K. (2019). Exploring students' acceptance of e-learning through the development of a comprehensive technology acceptance model. IEEE Access, 7, 128445-128462. https://doi.org/10.1109/ACCESS.2019.2939467

San Martín, H., \& Herrero, Á. (2012). Influence of the user's psychological factors on the online purchase intention in rural tourism: Integrating innovativeness to the UTAUT framework. Tourism Management, 33(2), 341-350. https://doi.org/10.1016/i.tourman.2011.04.003

Sanchez-Franco, M. J. (2010). WebCT - The quasimoderating effect of perceived affective quality on an extending Technology Acceptance Model. Computers \& Education, 54(1), 37-46. https://doi.org/10.1016/j.compedu.2009.07.005 
Saprikis, V., Markos, A., Zarmpou, T., \& Vlachopoulou, M. (2018). Mobile shopping consumers' behavior: An exploratory study and review. Journal of Theoretical and Applied Electronic Commerce Research, 13(1), 71-90. https://doi.org/10.4067/S0718-18762018000100105

Sarstedt, M., Ringle, C. M., Smith, D., Reams, R., \& Hair, J. F. (2014). Partial least squares structural equation modeling (PLS-SEM): A useful tool for family business researchers. Journal of Family Business Strategy, 5(1), 105-115. https://doi.org/10.1016/i.jfbs.2014.01.002

Seta, H. B., Wati, T., Muliawati, A., \& Hidayanto, A. N. (2018). E-learning success model: An extention of DeLone \& McLean IS' success model. Indonesian Journal of Electrical Engineering and Informatics, 6(3), 281-291. https://doi.org/10.11591/ijeei.v6i3.505

Shakya, S., Sharma, G., \& Thapa, K. B. (2017). State education system with e-learning in Nepal: Impact and challenges. Journal of the Institute of Engineering, 13(1), 10-19. https://doi.org/10.3126/jie.v13i1.20344

Sharif, A., Afshan, S., \& Qureshi, M. A. (2019). Acceptance of learning management system in university students: An integrating framework of modified UTAUT2 and TTF theories. International Journal of Technology Enhanced Learning, 11(2), 201. https://doi.org/10.1504/IJTEL.2019.098810

Sharma, S. K., Sharma, H., \& Dwivedi, Y. K. (2019). A hybrid SEM-neural network model for predicting determinants of mobile payment services. Information Systems Management, 36(3), 243-261. https://doi.org/10.1080/10580530.2019.1620504

Shaw, N., \& Sergueeva, K. (2019). The non-monetary benefits of mobile commerce: Extending UTAUT2 with perceived value. International Journal of Information Management, 45, 44-55. https://doi.org/10.1016/j.ijinfomgt.2018.10.024

Shin, D.-H., Shin, Y.-J., Choo, H., \& Beom, K. (2011). Smartphones as smart pedagogical tools: Implications for smartphones as u-learning devices. Computers in Human Behavior, 27(6), 2207-2214. https://doi.org/10.1016/i.chb.2011.06.017

Shiue, Y.-M., \& Hsu, Y.-C. (2017). Understanding factors that affecting continuance usage intention of gamebased learning in the context of collaborative learning. Eurasia Journal of Mathematics, Science and Technology Education, 13(10), 6445-6455. https://doi.org/10.12973/ejmste/77949

Siritongthaworn, S., Krairit, D., Dimmitt, N. \& Paul, H. (2006). The study of e-learning technology implementation: A preliminary investigation of universities in Thailand. Education and Information Technologies, 11(2), 137-160. https://doi.org/10.1007/s11134-006-7363-8

Spreng, R. A., MacKenzie, S. B., \& Olshavsky, R. W. (1996). A reexamination of the determinants of consumer satisfaction. Journal of Marketing, 60(3), 15-32. https://doi.org/10.1177/002224299606000302

Statista. (2019a). Kuwait: Gross domestic product (GDP) in current prices from 1984 to 2024. https:/ /www.statista.com/statistics/438858/gross-domestic-product-gdp-in-kuwait/

Statista. (2019b). Kunvait - Statistics \& facts. https:/ /www.statista.com/topics/4650/kuwait/

Stewart, K. A., \& Segars, A. H. (2002). An empirical examination of the concern for information privacy instrument. Information Systems Research, 13(1), 36-49. https://doi.org/10.1287/isre.13.1.36.97

Straub, D., \& Gefen, D. (2004). Validation guidelines for IS positivist research. Communications of the Association for Information Systems, 13. https://doi.org/10.17705/1CAIS.01324

Suh, B., \& Han, I. (2002). Effect of trust on customer acceptance of internet banking. Electronic Commerce Research and Applications, 1(3), 247-263. https://doi.org/10.1016/S1567-4223(02)00017-0

Sun, J., \& Hsu, Y. (2013). Effect of interactivity on learner perceptions in web-based instruction. Computers in Human Behavior, 29(1), 171-184. https://doi.org/10.1016/j.chb.2012.08.002

Sun, P.-C., Tsai, R. J., Finger, G., Chen, Y.-Y., \& Yeh, D. (2008). What drives a successful e-learning? An empirical investigation of the critical factors influencing learner satisfaction. Computers \& Education, 50(4), 11831202. https://doi.org/10.1016/j.compedu.2006.11.007

Susana, O., Juanjo, M., Eva, T., \& Ana, I. (2015). Improving graduate students' learning through the use of Moodle. Educational Research and Reviews, 10(5), 604-614. https://doi.org/10.5897/ERR2014.2052 
Susanto, A., Chang, Y., \& Ha, Y. (2016). Determinants of continuance intention to use the smartphone banking services: An extension to the expectation-confirmation model. Industrial Management \& Data Systems, 116(3), 508-525. https://doi.org/10.1108/IMDS-05-2015-0195

Tam, C., Santos, D., \& Oliveira, T. (2018). Exploring the influential factors of continuance intention to use mobile apps: Extending the expectation confirmation model. Information Systems Frontiers, 22(1), 243-257. https://doi.org/10.1007/s10796-018-9864-5

Taylor, S., \& Todd, P. A. (1995). Understanding information technology usage: A test of competing models. Information Systems Research, 6(2), 144-176. https://doi.org/10.1287/isre.6.2.144

Teo, T. (2011). Factors influencing teachers' intention to use technology: Model development and test. Computers \& Education, 57(4), 2432-2440. https://doi.org/10.1016/j.compedu.2011.06.008

Tran, L. T. T., Pham, L. M. T., \& Le, L. T. (2019). E-satisfaction and continuance intention: The moderator role of online ratings. International Journal of Hospitality Management, 77, 311-322. https://doi.org/10.1016/j.ijhm.2018.07.011

Uğur, N. G., Koç, T., \& Koç, M. (2016). An analysis of mobile learning acceptance by college students. Journal of Educational \& Instructional Studies in the World, 6(2), 39-49.

van Raaij, E. M., \& Schepers, J. J. L. (2008). The acceptance and use of a virtual learning environment in China. Computers \& Education, 50(3), 838-852. https://doi.org/10.1016/i.compedu.2006.09.001

Venkatesh, V., Brown, S. A., Maruping, L. M., \& Bala, H. (2008). Predicting different conceptualizations of system use: The competing roles of behavioral intention, facilitating conditions, and behavioral expectation. MIS Quarterly, 32(3), 483-502. https://doi.org/10.2307/25148853

Venkatesh, V., Morris, M. G., Davis, G. B., \& Davis, F. D. (2003). User acceptance of information technology: Toward a unified view. MIS Quarterly, 27(3), 425-478. https://doi.org/10.2307/30036540

Venkatesh, V., Thong, J. Y. L., \& Xu, X. (2012). Consumer acceptance and use of information technology: Extending the unified theory of acceptance and use of technology. MIS Quarterly, 36(1), 157-178. https://doi.org/10.2307/41410412

Verkijika, S. F. (2020). An affective response model for understanding the acceptance of mobile payment systems. Electronic Commerce Research and Applications, 39, 100905. https://doi.org/10.1016/j.elerap.2019.100905

Wang, W.-T., Ou, W.-M., \& Chen, W.-Y. (2019). The impact of inertia and user satisfaction on the continuance intentions to use mobile communication applications: A mobile service quality perspective. International Journal of Information Management, 44, 178-193. https://doi.org/10.1016/j.ijinfomgt.2018.10.011

Wichadee, S. (2105). Factors related to faculty members' attitude and adoption of a learning management system. The Turkish Online Journal of Educational Technology, 14(4), 53-61.

Wixom, B. H., \& Todd, P. A. (2005). A theoretical integration of user satisfaction and technology acceptance. Information Systems Research, 16(1), 85-102. https://doi.org/10.1287/isre.1050.0042

Wook, M., Yusof, Z. M., \& Nazri, M. Z. A. (2015). The acceptance of educational data mining technology among students in public institutions of higher learning in Malaysia. International Journal of Future Computer and Communication, 4(2), 112-117. https://doi.org/10.7763/IJFCC.2015.V4.367

Wu, B., \& Chen, X. (2017). Continuance intention to use MOOCs: Integrating the technology acceptance model (TAM) and task technology fit (TTF) model. Computers in Human Behavior, 67, 221-232. https://doi.org/10.1016/j.chb.2016.10.028

Yoo, W.-S., Lee, Y., \& Park, J. (2010). The role of interactivity in e-tailing: Creating value and increasing satisfaction. Journal of Retailing and Consumer Services, 17(2), 89-96. https://doi.org/10.1016/j.jretconser.2009.10.003

Zhang, M., Liu, Y., Yan, W., \& Zhang, Y. (2017). Users' continuance intention of virtual learning community services: The moderating role of usage experience. Interactive Learning Environments, 25(6), 685-703. https://doi.org/10.1080/10494820.2016.1172242 
Zhang, P. (2013). The affective response model: A theoretical framework of affective concepts and their relationships in the ICT context. MIS Quarterly, 37(1), 247-274. https://doi.org/10.25300/MISQ/2013/37.1.11

Zhao, X., Mattila, A. S., \& Eva Tao, L. (2008). The role of post-training self-efficacy in customers' use of selfservice technologies. International Journal of Service Industry Management, 19(4), 492-505. https://doi.org/10.1108/09564230810891923

Zhou, J. (2017). Exploring the factors affecting learners' continuance intention of MOOCs for online collaborative learning: An extended ECM perspective. Australasian Journal of Educational Technology, 33(5). https://doi.org/10.14742/ajet.2914

Zhou, M. (2016). Chinese university students' acceptance of MOOCs: A self-determination perspective. Computers \& Education, 92, 194-203. https://doi.org/10.1016/j.compedu.2015.10.012

Zhou, T., Lu, Y., \& Wang, B. (2010). Integrating TTF and UTAUT to explain mobile banking user adoption. Computers in Human Behavior, 26(4), 760-767. https://doi.org/10.1016/j.chb.2010.01.013

Zogheib, B., Rabaa'i, A., Zogheib, S., \& Elsaheli, A. (2015). University student perceptions of technology use in mathematics learning. Journal of Information Technology Education, 14, 417-438. https://doi.org/10.28945/2315

Zogheib, S., Rabaa'i, A. A., Zogheib, B., \& Saheli, A. E. (2015). University students' acceptance of technology in math classes: Does gender matter? Journal of Emerging Trends in Engineering and Applied Sciences, 6(4), 273287.

\section{AUTHORS}

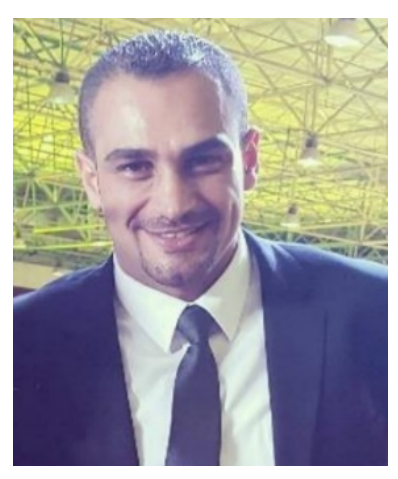

Ahmad A. Rabaa'i is an Associate Professor of Information Systems at New Jersey City University (NJCU) - School of Business, United States. He received a Ph.D. degree in Information Systems from Queensland University of Technology, Australia. Rabaa'i has published various books and peer-reviewed articles in conferences and journals. His research interests are in the areas of Enterprise Systems Implementation, Information Systems Evaluation, e-Government, Emerging Technologies, Technology Adoption/Acceptance, and Quality Assurance in Education.

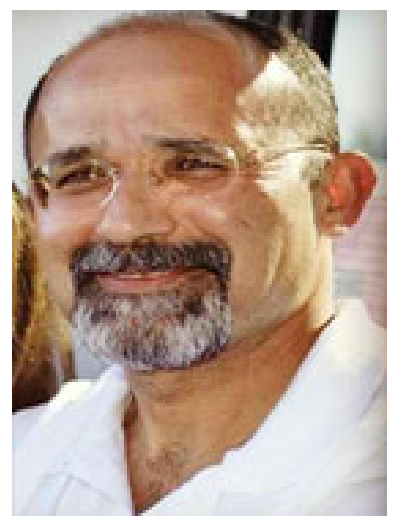

Shereef Abu Al-Maati is an Associate Professor of Computer Science at the American University of Kuwait (AUK). He was the Founding Division Head of the Sciences and Engineering Division from 2006-2012 and Department Chair of CSIS from 2012-2015. Prior to joining AUK, he was an Assistant Professor of Computer Science at the University of West Georgia, USA. Previously, he worked in industry at the Kuwait Institute for scientific research alongside IBM, Martin Marietta Data Systems, US Navy and Kuwait Air Force on automating the operational readiness of the Kuwait Air Force. He earned his studies from the Florida Institute of Technology where he received his Master of Science and PhD in Computer Science. 


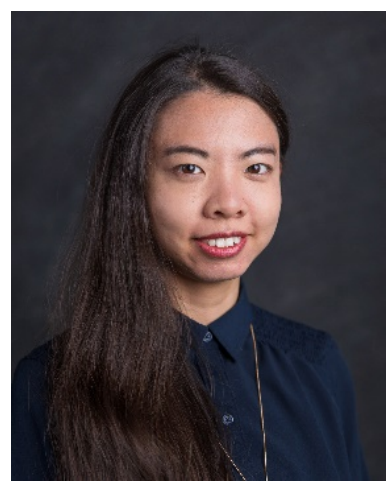

Xiaodi Zhu is an Assistant Professor at New Jersey City University, United States. She received a Ph.D. degree in Financial Engineering from Stevens Institute of Technology, U.S. Her current research interests focus on finance, data analysis and information systems, including behavioral finance, financial disclosure analysis, and portfolio analysis. Her research projects include mining textual data in the financial disclosures, studying the structure of financial statements, and firm's risk analysis. Dr. Zhu has published and presented her research at high quality journals and international conferences. 